\title{
A KÖZÉPÜLETEKBE VALÓ BELÉPTETÉS MINT KÖZIGAZGATÁSI JOGVITA ÉS A HATALMI ÁGAK SZÉTVÁLASZTÁSÁNAK KAPCSOLATA
}

https://doi.org/10.51783/ajt.2021.4.03

\begin{abstract}
A középületekbe való belépés megtiltása, elözetes engedélyezéshez kötése, vagy konkrét megakadályozása polgári, büntető és közigazgatási jogi eljárások sorát vonhatja maga után. A tanulmány célja annak vizsgálata, hogy a közigazgatási perrendtartás (Kp.) közigazgatási jogvita fogalma mennyiben tágította a közigazgatási perben való jogérvényesités lehetőségeit, akár a konkrét beléptetéssel összefüggő intézkedések, akár a kitiltással kapcsolatos egyedi utasítások, engedélyek, illetve az azokat megalapozó szabályzatok, általános hatályú rendelkezések tekintetében. A tanulmány tárgyalja azt is, hogy ez milyen hatással van a bírói hatalmi ág más hatalmi ágaktól való szétválasztásának elvére. Következtetésünk szerint a Kp. közigazgatási ítélkezés hatókörét erősitó törekvése a szigorú szétválasztás ellen hat.
\end{abstract}

\section{BEVEZETÉS - A KÖZÉPÜLET FOGALMA A TANULMÁNY TÁRGYA SZEMPONTJÁBÓL}

Ahhoz, hogy a középületekbe való beléptetéssel kapcsolatos közigazgatási jogviták tartalmi kérdéseit megvizsgálhassuk, mindenekelőtt szükséges e közigazgatási jogviták tárgyának pontos meghatározása.

Bár a középület fogalmát sokféleképpen definiálhatjuk, az elvi elválasztást általában az „épület” fogalmától jogorvoslati szempontból a polgári jogvita (birtokvédelem keretében önhatalom, birtokvédelmi jegyzői eljárás, illetve per), illetve a közigazgatási jogvita (közigazgatási per) lehetőségének felmerülése jelenti tanulmányunk tárgya szempontjából.

Közigazgatási jogvita akkor merülhet fel, ha az adott épületbe való belépés megtagadása esetén, ezen egyedi döntéssel való szembeszegülés megakadályozására az állam által birtokolt fizikai kényszer monopóliumának akár közvetlen, akár állami engedély alapján magánbiztonsági vagyonvédelmi vállalkozások által gyakorolt igénybevételének lehetősége áll fenn. Magyarán, ha állami fegyveres rendvédelmi szerv (katona, rendőr, országgyülési őrség stb.) vagy állami engedély alapján mükö-

* PhD, habilitált egyetemi docens, ELTE ÁJK, 1053 Budapest, Egyetem tér 1-3.

E-mail: andras.kovacs@ajk.elte.hu. 
dő fegyveres vagy akár fegyvertelen vagyonvédelmi vállalkozás tagjaként egyes rendészeti, személy- és vagyonvédelmi feladatokat ellátó személyek által védett egy épület, akkor merül fel a közigazgatási jogvita lehetősége is. Minden más esetben ez csak magánjogi vita tárgya lehet, a tulajdonos és mindenki más között.

Ezért a tanulmány tárgya szempontjából középületen minden olyan épületet értünk, amelyben működő szervezet közfeladatokat lát el, és amely épületben állami rendvédelmi vagy rendészeti szervek vagy vagyonvédelmi feladatokat ellátó személyek (vagyonőrök) végzik a ki- és beléptetést. Ebből a további szűkítésből következik, hogy magánterület vagyonőrökkel való védelmével összefüggésben előforduló esetleges intézkedések - jelen tanulmány levezetése alapján - bár lehetnek közigazgatási jogvita tárgyai bizonyos esetekben, de részletes vizsgálódásunk körén kívül esnek. Ezekről csak annyiban lesz szó, amennyiben fő témánk megértéséhez az szükséges.

Fontos kitérni rá, hogy amennyiben felmerül a közigazgatási jogvita lehetősége, az nem jelenti azt, hogy esettől függően, akár más jogágak ne léphetnének be párhuzamosan vagy mögöttesen a jogvédelmi eszközök közé. Tehát ha valamely beléptetés megtagadásával kapcsolatos jogvita közigazgatási jogvitának is minősülhet esetleg, ez nem zárja ki adott körülményektől függően a polgári jogi jogérvényesítést (pl. személyiségi jogsérelem, diszkriminációtilalom miatt) vagy akár a kényszerítő intézkedések alkalmazásával összefüggésben a büntetőeljárás lefolytatását sem (akár az intézkedő, akár az intézkedést elszenvedő tekintetében). Ezt fontos a tanulmány olvasása során mindvégig szem előtt tartani.

\section{A KÖZIGAZGATÁSI PERRENDTARTÁS HATÁLYBA LÉPÉSE ELŐTTI BÍRÓI GYAKORLAT}

Mindenekelőtt érdemes megvizsgálni, hogy a Kp. 2018. január 1-jei hatályba lépése előtt hogyan kezelte a kérdést a bírói gyakorlat.

A Kp. hatályba lépése előtti időszakban a bírósági épületekbe való beléptetés kapcsán vált a bírói joggyakorlat részévé ez a kérdés. Az egyik első, 2000-ben indult ügyben a Legfelsőbb Bíróság megállapította, hogy a bíróságokra való beléptetéskor a közhatalmat gyakorló szervezetek (értsd: bíróságok) szabályzata nem sért alkotmányos jogot, és nem jelenti a személyiségi jogok sérelmét amiatt, mert a jogtanácsosokat és ügyvédeket megkülönbözteti aszerint, hogy átesnek-e a biztonsági vizsgálaton, ha a differenciálás szabályozási cél szempontjából észszerűen indokolható pozitív diszkrimináció, és más szakmai körrel szemben nem méltánytalan. ${ }^{1}$ Ezt az elvet megerősítette pár évvel később a Legfelsőbb Bíróság, kimondva, hogy nem jelenti az egyenlő bánásmód követelményének megsértését, ha a megkülönböztetés nem önkényes, és van észszerü indoka. ${ }^{2}$ A Fővárosi Ítélőtábla egy másik ügyben kimondta, hogy a Legfelsőbb Bíróság épületébe történő be- és kilépés rendjét szabályozó belső szabályzat közérdekű adat, ${ }^{3}$ amelynek megismerése - és ezt

A Legfelsőbb Bíróság Pfv.IX. 21.999/2000/4 számú ítélete.

A Legfelsőbb Bíróság Pfv.IV.21.041/2005/6 számú ítélete.

3 A Fővárosi Ítélőtábla 2.Pf.20.444/2005/6 számú ítélete. 
mi tesszük hozzá - alapvető követelménye bármilyen további jogérvényesítésnek. Nem bírósági beléptetéshez kapcsolódott az a 2018-ban indult polgári ügy, amely már nem a Ptk. rendelkezésein, hanem az egyenlő bánásmódról és esélyegyenlőség előmozdításáról szóló 2003. évi CXXV. törvényen (a továbbiakban Ebktv.) alapult. Ebben kimondta a Legfelsőbb Bíróság, hogy az egyenlő bánásmód követelményét sérti az állatkerti szolgáltatást nyújtó alperes részéről az a magatartás, hogy a roller tiltására hivatkozva hosszabb ideig nem engedi be, és ezáltal megalázó helyzetbe hozza a mozgásában korlátozott, a rollert támasztékként, járást segítő eszközként használni kívánó személyt.

Világosan látszik, hogy a középületekbe való belépés diszkriminatív jellegével kapcsolatos polgári jogi kérdések a polgári törvénykönyv (Ptk.) és az Ebktv. diszkrimináció tilalmi rendelkezéseihez kapcsolódnak a gyakorlatban. Ezek a perek csak bizonyos szempontú tartalmi vizsgálatot tesznek lehetővé, azonban ha a beléptetési szabályzatnak meg nem felelő intézkedés történik, akkor az önkényesség hiánya és észszerű indok feltételei nehezen igazolhatók, illetve külön indokolást igényelnek.

Mindemellett megjelentek a közigazgatási perekben is ugyanezen ügyek. Az egyik ilyen ügy felperese a Legfelsőbb Bíróság épületébe akart belépni beadvány benyújtása céljából ügyfélfogadási időn kívül, nem elfogadva azt a tájékoztatást, hogy beadványát a kihelyezett gyüjtőládába kell dobnia. Az ebből kialakult vita során a felperes igazoltatására is sor került az intézkedő objektumőr rendőr részéről. A Legfelsőbb Bíróság megállapította, hogy a rendőrségről szóló törvény ${ }^{4}$ alapján a rendőrség a védett középületek és az abban tartózkodók biztonsága érdekében a középületben elhelyezett szerv vezetőjével (Legfelsőbb Bíróság elnöke) egyetértésben szabályokat állapíthat meg. A Legfelsőbb Bíróság épületébe történő belépést szabályozó belső szabályzat nem önhatalmú, jogszabályi alapot nélkülöző belső utasítás, hanem törvényi felhatalmazás alapján megalkotott szabályzat, amellyel összefüggésben igazoltatásra is sor kerülhetett, és vizsgálható volt az intézkedés szabályzatnak és jogszabályoknak való megfelelése, melyeknek az intézkedés megfelelt. ${ }^{5}$

Ettől eltérő eset volt, amikor a felperes Mohács város nyilvános testületi ülésén mint állampolgár részt kívánt venni, arról kép- és hangfelvételt készíteni. A mohácsi városháza bejáratánál feltartóztatta őt egy közterület-felügyelő és két biztonsági őr. A felperest az épületbe nem engedték be arra hivatkozva, hogy amennyiben lesz az ülésteremben a meghívottak körén kívül szabadon maradó ülőhely, akkor mehet fel az emeleten lévő terembe. A felperes telefonon rendőri segítséget kért, és a bejelentésre két rendőrjárőr megjelent a helyszínen. Az intézkedő rendőrök ezt követően felmentek az ülésterembe, majd arról tájékoztatták a felperest, hogy az ülésterembe azért nem mehet be, mert a terem befogadó képessége ezt nem teszi lehetővé, a polgármester így döntött. Ebben az ügyben a Kúria - utalva arra, hogy a közterület-felügyelet és a két biztonsági őr ellen nem terjesztettek elő panaszt -, megállapította, hogy a rendőrségi törvény szabályait a rendőrök betartották, és a Kúria arra is kitért, hogy a polgármester utasítására került sor arra, hogy felperest mozgásá-

4 A rendőrségről szóló 1994. évi XXXIV. törvény (Rtv.).

5 A Legfelsőbb Bíróság Kfv.II.39.091/2005/9. számú ítélete. 
ban akadályozták. A polgármester tevékenységének ellenőrzése pedig kívül esett az alperesi rendőrség hatáskörén. ${ }^{6}$

\section{INGATLAN ŐRZÉSE - RENDÉSZETI TEVÉKENYSÉG - KÖZIGAZGATÁSI TEVÉKENYSÉG}

Megállpítható az ismertetett esetjog alapján, hogy közigazgatási perben rendőri intézkedéssel szembeni panasz keretében nemcsak a rendőri intézkedés rendőrségi törvényben rögzített szabályai, de az is vizsgálható, hogy volt-e jogalapja az intézkedésnek. Ha szabályzat alapján közvetlenül a rendőr vagy esetleg rendőrségen belüli felettese dönt az intézkedésröl, akkor az intézkedés körébe tartozhat az intézkedés jogalapjának vizsgálata abból a szempontból, hogy az valamely jogszabályba ütközik-e. Ha viszont a jogszabálynak megfelel, de a beléptetési szabályzattal ütközik az intézkedés, és az önkényes, tehát nincs észszerủ indoka a szabályzattól eltérésnek, akkor az diszkriminatív lesz. Ez az egyenlő bánásmód elvét, illetve az egyenlő bánásmód törvény szabályait sérti, mely utóbbi törvény mind polgári, mind közigazgatási per kereteiben, így a rendőrségi intézkedés elleni panasz kivizsgálása körében is megállapítható. ${ }^{7}$

Fontos azonban, hogy ez az eljárásrend nem tudja kezelni azt az esetet, ha az intézkedés jogalapja az adott intézményben működő közfeladatot ellátó szerv valamely erre feljogosított egységének vagy magának a szerv vezetőjének az utasításán alapul (pl. polgármester). Vagy ami ezzel egyenértékủ, ha a szabályzat előzetes bejelentkezéshez és/vagy előzetes engedélyhez köti a jogszerű belépés lehetőségét, mely engedélyt a jogszabályok és a jogszabályoknak megfelelő szabályzatok keretei között adja ki az adott közfeladatot ellátó szerv valamely szervezeti egysége, esetleg a szerv vezetője. Ez esetben ugyanis a rendészeti feladatokat ellátó, középületet védő intézkedő személy az előzetes engedély hiánya, illetve külső (nem rendészeti feladatot ellátó szerven belüli) utasítás alapján jogszerủen cselekszik. Az utasítással a jogi felelősséget átvállaló szervezet, illetve személy pedig nem tartozik az intézkedéssel szembeni panaszeljárás hatálya alá. Más kérdés, hogy az ilyen személyek döntései is ütközhetnek jogszabályba, mely esetben megint csak az egyenlő bánásmód elvének sérelme, a személyiségi jogvédelem és az Ebktv. által biztosított jogvédelmi lehetőség kerülhetnek szóba.

Annak az eljárásrendnek a kialakítása, hogy azon rendészeti intézkedések, amelyek nem büntetőeljárás vagy szabálysértési eljárás részei, a közigazgatási bíróság által felülvizsgálhatók, a Legfelsőbb Bíróság 1/1999 Közigazgatási Jogegységi Határozatán (a továbbiakban: jogegységi határozat) alapul. A jogegységi határozat kimondta a rendőri szerv vezetőjének panasz elbírálása tárgyában hozott határozatáról, hogy az közigazgatási határozat, és ekként bíróság által felülvizsgálható. Az indokolás szerint kifejezetten azon az alapon tekinthető közigazgatási határozat-

6 A Kúria Kfv.III.38.091/2018/4. számú ítélete, lásd különösen az indokolás 25. pontját.

7 Lásd az Ebktv.12. §-ában rögzített általános felhatalmazást. 
nak, hogy közigazgatási tevékenységről van szó, a rendészeti igazgatási feladatok ellátása közhatalom gyakorlása. Igaz, utalt arra is, hogy államigazgatási ügy gyakorlására feljogosított szerv a rendőrség, melyből szintén következik, hogy rendőr és az intézkedés (kényszerítés) alanya között annak minden jellemzőjével rendelkező közigazgatási jogviszony jön létre.

Ennek a döntésnek a jelentőségét aligha lehet túlhangsúlyozni, mert az általunk vizsgált kérdés „jogi rákfenéjének” és nehézségének a lényegi elemét mutatja meg. Eljárásjogi-dogmatikai szempontból világosan látszik, hogy egy új típusú eljárást alakított ki ez esetben a Legfelsőbb Bíróság, és egy közérdekủ bejelentések és panaszokról szóló törvényi szabályozási keretben ${ }^{8}$ értelmezhető esetet alakított át hatósági üggyé. Ezt az újítást az tette lehetővé, hogy a jogalkotó is felismerte az ilyen panaszok eltérő kezelésének valamilyen szükségességét a határozati formában való döntéssel (levélben való válaszadási kötelezettség helyett). ${ }^{9}$ Ezért lehetett az akkori eljárási törvény, az Áe. hatósági ügyekre kiterjedő jogorvoslati rendjét alkalmazni az ügyre, noha ennek egyéb eljárásjogi feltételei alig álltak fenn. Hiszen a szerv vezetője a saját állománya (rendőrei) intézkedésének jogszerűségéröl dönt, az intézkedő rendőrök nem ellenérdekü ügyfelek az eljárásban, noha a panasznak történő helyt adás rájuk nézve járhat súlyos következményekkel. Ennek ellenére legfeljebb tanúként szerepelnek az ilyen ügyekben. ${ }^{10}$ Ezt a problémát a „2006-os őszi eseményeket” követően felállított Független Rendészeti Panasztestület közbeékelése sem oldotta meg, ahogy e testület 2020. évi megszüntetése sem vezetett a tételes jogi szabályozás fejlődéséhez.

Anélkül, hogy ennek elemzésében elmerülnénk, az leszögezhető, hogy a jogegységi határozat megfogalmazta az elvi igényt a hatósági intézkedésekkel szembeni jogorvoslat szükségessége tekintetében, mely igényt el is ismert olyan esetben, ha arra a tételes jog valamely külön rendelkezése is alapot adott, mint az Rtv. alapján meghozott rendőri intézkedések esetében Ugyanakkor indokolásában általános tételt fogalmazott meg - igen helyesen - a tekintetben, hogy a rendészeti jog, a rendészeti igazgatás körébe eső cselekmények közigazgatási cselekmények. Az igény a hatósági intézkedésekkel szembeni jogorvoslatra pedig alkotmányosan is fontos

8 A jogegységi határozat meghozatalakor az 1977. évi I. törvény, aztán a 2004. évi XXIX. törvény 141-143. §-ai, majd a panaszokról és közérdekű bejelentésekről szóló 2013. évi CLXV. törvény szabályozza akként az egyéni panaszokat, hogy amikor nincs hatósági vagy más jogorvoslati út, akkor lehet panaszt benyújtani, melyre a közigazgatási szerv levélben köteles válaszolni, esetleg a felügyeleti szervhez lehet fordulni válaszért. Ez a jogviszony viszont nem hatósági jogviszony, így formális jogorvoslat a válaszlevéllel szemben nem biztosított.

9 Ez a megoldás nem egyedülálló a közigazgatási jogi szabályozásban. Hasonló a helyzet a tisztességtelen piaci magatartás és versenykorlátozás tilalmáról szóló 1996 évi. LVII. törvény (Tpvt.) 43/GH. §-aiban szabályozott bejelentési eljárások tekintetében. E rendelkezések korábban általánosan, jelenleg formanyomtatványon teszik lehetővé bejelentés megtételét, melyhez a törvény sui generis jogorvoslati eljárást kapcsol, noha elvileg hatósági jogviszony nem is jön létre. A bíróságnak a jogorvoslat során arról kell döntenie, hogy a bejelentés alapján indítson-e hatósági eljárást a GVH, vagy nem.

10 Ennek elemzéséről lásd részletesen Kovács András György: „Vannak-e a bepanaszolt rendőrnek alkotmányos jogai” Rendészeti Szemle 2009/9. 3-24. 
követelmény. ${ }^{11}$ Bár a jogegységi határozat nem hivatkozik az Alkotmányra, de világos az alkotmányos jogállami felfogás attitűdjének megjelenése. Ez visszaigazolja azt az általánosan élő kelet-európai tapasztalatot, hogy az állam erőszakszervezeteinek jogsértő fellépése ellen - ami nem elvi, hanem nagyon is gyakorlati probléma - kell közigazgatási jogorvoslatot biztosítani egy jogállamban.

Ebből már egyenesen következett az az üzenet, hogy minden rendészeti igazgatás körébe vonható intézkedés esetében a közigazgatási jogorvoslat biztosított legyen. Ha megnézzük a ma hatályos egyes rendészeti feladatokat ellátó személyek tevékenységéröl, valamint az egyes törvényeknek az iskolakerülés elleni fellépést biztosító módosításáról szóló 2012. évi CXX. törvényt (a továbbiakban: rendészeti törvény), akkor azt látjuk, a rendészeti feladatokat ellátó személy, valamint a személy- és vagyonőr az intézkedésről, amennyiben kényszerítő eszközök alkalmazására is sor került, szóban - haladéktalanul, rövid úton - jelentést kell tegyen munkáltatójának. Majd írásbeli jelentést is kell készítenie, melyben többek közt meg kell jelölnie az alkalmazást lehetővé tevő valamennyi jogszabályra való hivatkozást, melyet a munkáltató köteles kivizsgálni. ${ }^{12}$

Akinek a rendészeti törvény szerinti, személy- és vagyonőr esetében a személyés vagyonvédelmi, valamint a magánnyomozói tevékenység szabályairól szóló törvény ${ }^{13}$ szerinti kényszerítő eszköz alkalmazása jogát vagy jogos érdekét sértette, a személy- és vagyonőr esetében a személy- és vagyonvédelmi törvényben meghatározott kamarához, minden más esetben a rendészeti feladatokat ellátó személy intézkedésével szemben a rendőrséghez fordulhat panasszal. ${ }^{14}$ Kifejezetten utal arra a rendészeti törvény, hogy a panaszról a közigazgatási hatósági eljárás szabályai szerint kell dönteni. ${ }^{15}$ Ebben az esetben elöbb fellebbezésnek, majd az így hozott határozattal szemben - immár a Kp. szabályai alapján - közigazgatási pernek van helye. A személy- és vagyonvédelmi törvény szintén kifejezetten kimondja, hogy a kamarai döntést a panasz elbírálása során a közigazgatási hatósági eljárás szabályai szerint kell meghozni, amely ellen fellebbezésnek van helye ${ }^{16}$ és amely szintén a Kp. szabályaira figyelemmel közigazgatási perben lesz támadható. Tekintettel arra, hogy az intézkedésről készült írásbeli jelentésben kifejezetten meg kell jelölni jogszabályi előírás folytán az intézkedés jogalapját képező összes jogszabályhelyet, nemcsak az intézkedés módja, hanem annak jogalapja is ezen eljárások tárgya.

Függetlenül attól tehát, hogy a rendőrségi törvény, valamint a rendészeti törvény hatálya alá tartozó, állami szervek fizikai kényszert megvalósító, a szakirodalom-

${ }^{11} \mathrm{Az}$ angolszász jogrendszerekben természetes a közvetlen hivatkozás alkotmányos jogra, nálunk nem. Dojcsák Dalma - Szabó Máté Dániel: „Egy nyert strasbourgi ügy is lehet jogvédő szemmel sikertelen - elérni kívánt és teljesületlen célok a Mándli és mások ügyében" Fundamentum 2020/4. 129.

${ }^{12}$ Rendészeti törvény 22. § (1), (2), (3) bekezdés j) pont.

${ }^{13}$ A személy- és vagyonvédelmi, valamint magánnyomozói tevékenység szabályairól szóló 2005. évi CXXXIII. törvény (továbbiakban személy- és vagyonvédelmi törvény).

${ }^{14}$ Rendészeti törvény 22 . $§(4)$ bekezdés.

${ }^{15}$ Rendészeti törvény 22. $§(6)$ (7) bekezdés.

${ }^{16}$ Személy- és vagyonvédelmi törvény $62 / \mathrm{A}$. §. 
ban ${ }^{17}$ „hatósági közegnek” nevezett tagjairól van szó (beleértve a közterület-felügyelőt, halőrt stb.), vagy esetleg a személy- és vagyonvédelmi törvény hatálya alá tartozik az adott intézkedő személy, intézkedésének jogalapja és módja jogszerűségének vizsgálata közigazgatási hatósági eljárás keretei között lefolytatott panasz eljárásra tartozik. A személy- és vagyonvédelmi törvény szerint személy- vagyonvédelmi tevékenységnek minősül természetes személyek életének és testi épségének védelme, és a jelen tanulmány szempontjából fontos ingatlan, illetve ingóság őrzése. ${ }^{18}$

Levonhatjuk ezért a következtetést, hogy ha valamely személynek ingatlan őrzése a feladata, és ilyen feladatot csak a rendőrségi és rendészeti törvény, illetve ahhoz kapcsolódó más törvények felhatalmazása alapján ${ }^{19}$ vagy a személy- és vagyonvédelmi törvény alapján láthat el arra felhatalmazott vállalkozás vagy személy, akkor függetlenül attól, hogy középület vagy más épület őrzéséről van szó, intézkedése - beleértve annak jogalapját is - közigazgatási hatósági ügynek minősül. Ebben a közigazgatási hatósági ügyben hozott határozat közigazgatási perben a Kp. szabályai alapján minden kétséget kizáróan támadható.

Fontos leszögezni, hogy a jogalkotó kénytelen volt teljes körủen biztosítani minden rendészeti tevékenységgel - ezen belül épület őrzésével - kapcsolatban a hatósági eljárást és a közigazgatási pert. Hiszen ha ezt nem teszi, akkor a jogegységi határozat indokolásából kitűnően alkotmányos szabályok sérültek volna, mert az indokolás szerint közigazgatási jogviszonyról van szó ezekben az esetekben. Márpedig a közigazgatási döntésekkel szemben a korábbi Alkotmány is biztosította a jogorvoslatot és külön a bírói jogorvoslatot. A jogrendszer ezen része a Kp. hatályba lépésig ezért csak külön jogorvoslati szabályok bevezetésével volt alkotmányosnak tekinthető, mert a jogaiban sértett állampolgárok számára kizárólag hatósági ügyekben teremtette meg a Pp. XX. fejezete a közigazgatási bírói jogorvoslatot, szemben az Alkotmánnyal, majd az Alaptörvénnyel, amely minden közigazgatási döntés ellen elvárta és elvárja a jogorvoslat biztosítását.

Mindezért bizton állíthatjuk, hogy a magyar jogi hagyomány, épp a kedvezőtlen kelet-európai tapasztalatokból is okulva az, hogy minden rendészeti igazgatási tevékenység ${ }^{20}$ a Kp. szóhasználatában közigazgatási tevékenység (közigazgatási

17 FAzeKAS Marianna: „A hatósági jogalkalmazó aktusok” in Közigazgatási jog, Általános rész III. (Budapest: ELTE Eötvös Kiadó 2020) 97.

18 Személy- és vagyonvédelmi törvény 1 . $§(2)$ bekezdés.

$19 \mathrm{Pl}$. a fegyveres biztonsági őrségről, természetvédelmi és mezei őrszolgálatról szóló 1997. évi CLIX. törvény, mely szintén ugyan párhuzamosan, de kifejezetten szabályozza a panaszeljárást hatósági eljárásként. Lásd még 487/2017. (XII.29.) Korm. rendelet közigazgatási hatósági eljárásokhoz kapcsolódó hatásköri szabályait.

${ }^{20}$ Nem képezi elemzésünk tárgyát a honvédelmi igazgatás és annak körébe eső rendészeti tevékenységek, melyek összetett és bonyolult kérdéseket vetnek fel, és tárgyalásuk önálló tanulmányt igényelne. Pl. nem az államigazgatás része a honvédelmi igazgatás szervei, ugyanakkor kérdés, mi számít ezen tevékenységek közül kormányzati tevékenységnek. Figyelemmel a különleges jogrendre vonatkozó szabályok változásaira is, itt a törvényességi kontroll hiánya a Kp. előtti állapotokhoz képest is egyre feltűnőbb, és e tevékenységek mind kontrollálhatatlanabbá válnak. Lásd pl. VöRös Imre: „Különleges jogrend katonákkal - mindörökké?” http://ekint.org/lib/documents/1610007006Publ_Voros_Imre_Kulonleges_jogrend_katonakkal.pdf. 
cselekmény, illetve cselekmény elmulasztása), és ennek egyértelmủ bírói gyakorlata volt már a Kp. hatályba lépése előtt is

Még ha teljeskörűségre törekedett is a jogalkotó az alkotmányos követelmények biztosítására figyelemmel, a szabályozás esetlegessége nem volt alkalmas arra, hogy kezelje azt a problémát, ha az ingatlan őrzése, mely immanens módon magában foglalja a be- és kilépésről való intézkedést, elválik a be- és kilépésről való döntéstől, és azt más személy végzi. Ez esetben, ha az intézkedés jogalapja az épületben működő közfeladatot ellátó szerv szervezeti egysége vagy vezetője egyedi és előzetes engedélyén alapszik, akkor erre az egyedi döntésre a panaszeljárások értelemszerűen nem terjednek ki.

A mind a magáningatlanokra, mind a középületekre egyformán kiterjedő szabályozás arra utal, hogy ezek az elkülönülő egyedi döntések valójában az épület üzemeltetésével összefüggő tulajdonosi döntések. Ha egy közfeladatot ellátó szerv müködteti az épületet, akkor a szervi müködés körébe eső aktusról van szó, és nem a szakmai müködés körébe tartozó döntésről. Ugyanakkor az épületben folyó szakmai működés közigazgatási vagy akár más közjogi szabályai eredményezhetik azt, hogy e szabályok a szervi aktus folytán sérülnek. Például egy olyan szervi-üzemeltetési döntés, hogy a bírósági tárgyalásra érkező állampolgárt vagy felet nem engedik be a bíróság épületébe, bele fog ütközni a tárgyalás nyilvánosságának szabályába. Eljáró fél esetén beleütközhet más olyan perjogi szabályba, mely a fél be nem engedése esetén kimentésre ad alapot, és a tárgyalás megismétlését eredményezi. Tárgyalást hallgató kizárása esetén nyilvánosság sérelme folytán olyan sérelemre kerül sor, mely a konkrét bírósági eljárásban nem orvosolható, és a törvénysértés bekövetkezik. Az ilyen közjogi-közigazgatási szabályok ezért korlátai a tulajdonosi döntéseknek, míg ha csak a belépésre vonatkozó belső szabályzat megsértésére kerül sor önkényesen, észszerű indok nélkül, akkor az diszkriminatív döntés lehet az Ebktv. szabályai alapján, és adott esetben személyiségi jogi igényként kérhető számon.

\section{BELÉPTETÉS ELŐZETES ENGEDÉLYEZÉSE ÉS A HATÓSÁGI INTÉZKEDÉSEK ${ }^{21}$ MINT EGYEDI DÖNTÉSEK}

A Kp. 4. § (1) bekezdése értelmében a közigazgatási jogvita tárgya a közigazgatási szerv közigazgatási jog által szabályozott, az azzal érintett jogalany jogi helyzetének megváltoztatására irányuló vagy azt eredményező cselekményének, vagy a cselekmény elmulasztásának (a továbbiakban együtt: közigazgatási tevékenység) jogszerűsége. Közigazgatási cselekmény a (3) bekezdés szerint többek közt az egyedi döntés s az egyedi ügyben alkalmazandó - jogalkotási törvény hatálya alá nem tartozó - általános hatályú rendelkezés.

${ }^{21}$ A hatósági intézkedések fogalmát a tanulmányban nem az Ákr. fogalomhasználata, hanem az egyetemi tankönyvek fogalomhasználata szerint, mint jogdogmatikai fogalmat használom. Eszerint a hatósági intézkedés olyan közigazgatási intézkedés, melyre hatósági üggyel összefüggésben kerül sor. A fogalmi elemek vonatkozásában lásd: 18. lj. uo. 
Ha az ingatlant őrző vagyonvédelmi őr (legyen az rendőr vagy egyszerű biztonsági őr) az adott középületben müködő közigazgatási szerv valamely egységének vagy vezetőjének az előzetes engedélye alapján engedhet-be egy adott személyt az épületbe, akkor ezek a döntések - még ha egyszerủ e-mailes értesítésben indokolás nélkül jelennek is meg - ugyan eljárási törvényi garanciák nélküli, de egyedi döntések és egyben közigazgatási cselekmények, amennyiben a másik két feltétel fennáll.

E másik két feltétel, hogy közigazgatási szerv egyedi döntéséről, vagy általános hatályú rendelkezéséről legyen szó, és a döntés közigazgatási jog által szabályozott legyen, illetve az általános hatályú rendelkezés közigazgatási jogi szabályokat tartalmazzon. A Kp. szerinti egyedi döntésnek ugyanis nem kell hatósági döntésnek lenni, elegendő, hogy joghatást váltson ki. Az sem lehet vitás, hogy az épületbe való beléptetést elöíró szabályzatok nem közjogi szervezetszabályozó eszközök, többek között azért sem, mert a szervezeti viszonyokon kívüli, kifelé ható joghatásokat váltanak ki. Ezzel szemben a közjogi szervezetszabályozó eszközök joghatásai csak a szervezeti viszonyokat szabályozhatják, azaz befelé, a belső jogviszonyokra hatnak. Mivel az ilyen szabályzatok nem jogszabályok, és a Jat. a jogszabályokat és a közjogi szervezetszabályozó eszközöket szabályozza, ezért ezek a Jat. alatti általános hatályú rendelkezések, melyek az egyedi döntéssel együtt támadhatók közigazgatási perben.

Ezen levezetéssel szemben legfeljebb az vethető fel, hogy a Kp. eredeti, 2018. január 1-jén hatályba lépett szabályozásában a Kp. 4. § (3) bekezdés b) pontja a közigazgatási cselekmények között a hatósági intézkedést külön nevesítette. Ugyanakkor 2019. december 20-ától a jogalkotó a b) pontot hatályon kívül helyezte, melyből formállogikai alapon az a következtetés is levonható, hogy a hatósági intézkedések nem egyedi döntések, és mivel a hatósági intézkedések (a rendészeti fellépések is idetartoznak) már nem közigazgatási cselekmények, ezért ezekkel szemben a Kp. alapján nincs perorvoslatnak helye, csak akkor, ha erről külön jogszabály rendelkezik.

Mint láttuk, a magyar jogrendben a külön jogszabályok az ilyen hatósági intézkedések (sőt a nem hatósági közegek által tett, de rendészeti fellépések) elleni panaszok elbírálását zárt logikai rendben szabályozzák, és minden esetben a panaszok hatósági eljárás keretében való elbírálását írják elő. Mindezért aligha vitatható, hogy az ilyen rendben hozott döntések már egyedi döntések, mégpedig azon belül hatósági döntések. Fontos leszögezni ugyanakkor, hogy ez a tételes jogi visszalépés nem változtat azon a szintén formállogikai szabályon, hogy egy hatósági intézkedés maga is egyedi döntéseken alapszik.

Az eredeti szövegezésben tehát a hatósági intézkedések kiemelése csak a kérdés fontosságát jelezte, mely fontosság világos az alaptörvényi vonatkozások, a jogegységi határozat és a korábbi gyakorlatban betöltött szerepre tekintettel. A hatósági döntések helyett a Kp.-val bevezetett egyedi döntések fogalma magában foglalja a rész-egész viszonyra tekintettel a hatósági intézkedéseket is, hisz fogalmilag azok is döntések, csak nem hatósági döntések. Az egyedi döntés fogalma tehát magában foglal bármely döntéselméleti szempontból döntésnek tekinthető döntést. ${ }^{22}$

${ }^{22}$ Hasonló következtetést fogalmazott meg BaraBÁs Gergely - Kovács András György: „Ket. 12.§” in BARABÁs Gergely - BARANYI Bertold - Kovács András György (szerk.) Nagykommentár a közigazgatási eljárási törvényhez (Budapest: Complex 2013) 52-54., F. Rozsnyal Krisztina: Hatékony 
Mindezért megállapítható, hogy a hatósági intézkedések megjelenése a Kp. szövegében csak egy kiemelés volt az egyedi döntések köréből, amit megerősít az a tény is, hogy a Kp. hatályba lépése előtti eredeti tervezetben ez még nem zártkörü, hanem csak példálózó (így különösen) felsorolás lett volna a generálklauzulaként meghatározott „közigazgatási jogvita” fogalom mellett törve lándzsát az enumerációval szemben. ${ }^{23}$ Tehát már az eredeti megfogalmazáskor sem tekintette a jogalkotó ebben a felsorolásban megjelenő eseteket egymást kizáró kategóriáknak, hisz a felsorolást nem enumeratív felsorolásnak szánta. Ezért továbbra is a Kp. generálklauzula szabálya alapján akkor is lehet hatósági intézkedésekkel összefüggésben közigazgatási pert kezdeményezni, ha egyébként külön jogszabály az ilyen intézkedések ellen benyújtott panaszokat nem minősítené eleve hatósági ügynek, vagy nem is rendelkezne az intézkedések elleni panaszokról.

Fontos kitérni az egyedi döntés fogalmának meghatározásakor, hogy az Országgyülés által hozott döntés egy törvényröl azért nem lesz egyedi döntés, mert a törvény fogalmilag normatív tartalmú és nem egyedi, addig egy polgári jogi jogügyletről való döntés egyedi döntés. Ez utóbbi viszont azért nem tartozik a Kp. hatálya alá, mert a másik két fogalmi elem, az, hogy közigazgatási szerv hozta, illetve közigazgatási jog által szabályozott kérdésben és körben hozták volna meg a döntést, nem áll fenn.

Az igazi kérdés az, hogy a hatósági intézkedések, továbbá az előzetes beléptetési engedélyek mint egyedi döntések közigazgatási egyedi döntések-e, illetve az ezen döntéseket megalapozó normatív szabályok közigazgatási általános hatályú rendelkezések-e. ${ }^{24} \mathrm{Ha}$ ezt a minőségüket meg tudjuk állapítani, akkor elvileg az ilyen egyedi döntéseket kiadó szerveket közigazgatási szerveknek kell tekinteni. Az alábbiakban ez utóbbi állást vizsgáljuk meg részletesebben.

\section{A KÖZIGAZGATÁSI SZERV FOGALMA}

A Kp. 4. § (7) bekezdésének 1. pontja az államigazgatási szerveket (és közegét), a helyi és nemzetiségi önkormányzatok szerveit, a köztestületek és felsőoktatási intézmények önálló feladat- és hatáskörrel rendelkező szervezeti egységeit és eljáró tisztviselőit, közegét automatikusan közigazgatási szerveknek tekinti, és az e bekezdés 1. e) pontja alapján idetartozik minden jogszabály által közigazgatási cselekmény megvalósítására feljogosított egyéb szervezet vagy személy is.

jogvédelem a közigazgatási perekben (Budapest: ELTE Eötvös Kiadó 2018) 71-72. Legutóbb: F. Rozsnya Krisztina: „Variációk egy témára: a közigazgatási ügyben eljáró bíróságok és hatásköreik” Jogtudományi Közlöny 2020/2. 90. 39. lj.

${ }^{23}$ F. RozSNYAI Krisztina: Hatékony jogvédelem a közigazgatási perekben (Budapest: ELTE Eötvös Kiadó 2018) 53-59.

${ }^{24}$ Külön jogelméleti és dogmatikai problémát vet fel, hogy egy egyedi döntés - ha az nem az Ákr. rendje alapján meghozott hatósági döntés mikor végleges, ennek a témának az önálló tárgyalása azonban szétfeszitené a tanulmány kereteit. 
Ez azt jelenti, hogy a rendvédelmi szervek mint államigazgatási szervek ${ }^{25}$ által foganatosított intézkedések a fenti (7) bekezdés 1. a) pontja alapján közigazgatási szervek, míg a személy- és vagyonvédelmi törvény alapján eljáró vállalkozások ingatlan őrzése körébe eső tevékenységük során azért lesznek közigazgatási szervek, mert az e) pont alapján külön törvényi szabályozás szerint ezek az intézkedések közigazgatási eljárás keretében vizsgálhatók ki.

Az egyik legfontosabb vizsgálandó kérdés az, hogy ez utóbbi megállapítás a helyes, vagy esetleg elegendő a rendészeti jellegű tevékenység végzésére adott jogszabályi felhatalmazás, amely önmagában olyan feljogosítást jelent, amely az e) pont alapján közigazgatási szervvé minősíti át az ilyen magánvállalkozások rendészeti tevékenységét. A feljogosítás kifejezett volta a két eset között a különbség, ami egyben eldönti azt is, hogy e vonatkozásban az e) pont generálklauzulának tekinthető-e a közigazgatási szervek vonatkozásában, vagy épp ellenkezőleg, kifejezetten megköveteli minden e) pont alá tartozó esetben a kifejezett Kp.-töl eltérő törvényi rendelkezést. A Kp. 4. § (7) bekezdés 1. e) pontjából viszont az mindenképp következik, hogy ha külön jogszabály rendészeti cselekmények megvalósítására feljogosít valamely, a fentebb felsorolt szerveken túlmenően szervezeteket, tartozzanak ezek magánjogi szervezetek vagy más államhatalmi szervek körébe a hatalommegosztás rendszerében, egyaránt közigazgatási szerveknek minősülhetnek - e rendészeti cselekmények tekintetében.

Ennél a pontnál azonban tisztázni szükséges e jogértelmezésnek más Kp.szabályokkal való kapcsolatát, mert csak akkor fogadható el ez az értelmezés, ha más Kp.-szabályokkal összhangban áll.

\section{KÖZIGAZGATÁSI JOGVITA VS. EGYÉB KÖZJOGI JOGVITA}

E körben elsősorban a Kp. 5. §-át kell figyelembe vennünk, amelynek első bekezdése rögzíti, hogy közigazgatási jogvitát a bíróság közigazgatási perben bírálja el, míg a második bekezdés szerint a bíróság közigazgatási perben dönt azon közjogi jogvitában is, amelynek elbírálását a törvény a közigazgatási ügyben eljáró bíróság hatáskörébe utalja.

A jogalkotó megkülönbözteti a közigazgatási jogvita és az egyéb közjogi jogvita fogalmát, mert az egyéb közjogi jogviták nem közigazgatási jogviták, nem tartoznak automatikusan közigazgatási perre, csak ha azt külön törvény kimondja. Ez a szabály a közigazgatási jogvita általános fogalmát szükíti mind tárgya, mind az alanyi kör tekintetében. Az egyéb közjogi jogvita tárgya nem közigazgatási jog, hanem az azon kívül eső közjog, magyarán alkotmányjog által szabályozott kört fedi le, míg a közigazgatási jogvitának, mivel a közigazgatási jogi szabályok is az Alaptörvényen alapulnak, tárgya lehet közigazgatási jogi szabály, illetve azzal összefüggésben alaptörvényi norma is. Sőt, kivételesen nem zárható ki tisztán alaptörvényi szabályon

${ }^{25}$ A központi államigazgatási szervekről, valamint a Kormány tagjai és államtitkárok jogállásáról szóló 2010. évi XLIII. törvény (Ksztv.) 1. § (5) bekezdés. 
alapuló jogvita sem. Tárgya alapján ezért általában lehetséges, de nem minden esetben lehetséges az elhatárolás.

Ami a közjogi jogviszonyok alanyi körét illeti: nem a közigazgatási szerv [amely a Kp. 4. § (7) bekezdés 1. e) pontja alapján lehet bármely közjogi szerv is elméletileg] és ügyfél közötti, tehát nem az államhatalmi szerveken kívüli jogalanyokkal létrejövő közhatalmi jogviszonyokra vonatkoznak az egyéb közjogi jogviták, mert ha arra vonatkoznának, akkor közigazgatási jogvita tárgyát képező közigazgatási jogviszonyokról volna szó. Az egyéb közjogi jogvita a közjogi jogalanyok közötti, közhatalmi szervek, illetve személyek közötti, nem hierarchián, illetve nem vezetési és irányítási jogviszonyokon alapuló vitát fedi le.

Míg közigazgatási jogvita tárgya lehet közjogi szerven belüli közigazgatási jogviszonyt változtató hatású közigazgatási cselekmény, például a közszolgálati jogviták egy része, illetve lehet közjogi szervezetrendszeren belüli szervek közötti jogvita (pl. közigazgatási szerződésekből eredő jogviták egy része), ${ }^{26}$ de lehet kifelé irányuló jogviszony is, sőt ez a tipikus, addig egyéb közjogi jogvita csak közjogi szervezetrendszeren vagy szerven belüli közjog, alkotmányjog által szabályozott jogvita lehet.

Ez utóbbi pontos meghatározására nem törekszünk, mivel nem ez a fö tárgya a tanulmánynak, de két példával érzékeltetni szeretnénk: ha a Kúria elnöke és a Kúria bírája között jogvita alakul ki, az egyéb közjogi jogvita, mely azonban nem tartozik a Kp. hatálya alá, hanem külön szabályok szolgálati bíróság elé utalják, vagy munkaügyi jogvita tárgya lehet. Az Országgyűlés elnöke és a képviselők közti jogvita, például az országgyülési törvény alapján kiszabott rendbírság vitatása, szintén az Országgyülés mint testület elnöke és a testület tagjai közötti belső jogviszonyból eredő egyéb közjogi jogvita. Ez esetben nem hatóság és ügyfél viszony áll fenn, hanem a testület elnöke mint közjogi méltóság és a képviselő mint közjogi szereplő, a testület tagja (és nem mint magánszemély) között alakul ki a vita.

Érdekes az az esetkör, ha például a sajtó képviselőjét tiltja ki a házelnök a nyilvános ülésről, hiszen a sajtó képviselője, bár belépésével elismeri, hogy az Országgyülés elnöke által meghatározott parlamenti jog hatálya alá tartozik, ${ }^{27} \mathrm{de} \mathrm{a}$ belépés előtti tiltás mindenképp külső jogviszonyban jelentkezik, hisz a sajtó képviselője, de maga a sajtó is közhatalmon kívüli magánszemély, illetve szervezet. Ekként a köztük ebben fennálló jogvita nem lehet egyéb közjogi jogvita. Ez ahhoz az érdekes helyzethez vezethet, hogy míg a közigazgatási jogvita lehetőségét az eddigi érvelésünk legalábbis nem zárja ki a sajtó egy képviselője és az Országgyủlés elnöke közti jogvitában, addig az Országgyülés elnöke és egy országgyülési képviselő között egyéb közjogi jogvita merül fel, amelyre a Kp. nem terjed ki, és nincs is olyan törvény, amely biztosítaná a bírói jogorvoslatot, kivéve az Országgyülési Őrség hatósági intézkedésével szemben. ${ }^{28}$

${ }^{26}$ Közigazgatási szerződésből eredő viták belső viszonyokra vonatkoznak, ha mindkét szerződő fél közigazgatási szerv, és e minőségében szerződik egymással.

27 3207/2013. (XI.18.) AB határozat [41]-[47] megfontolások.

${ }^{28}$ Ahogy fentebb volt róla szó, a szabályozás tételes jogilag zárt rendszert alkot. Az Országgyűlési Őrség intézkedéseire a rendőrségi törvényt kell alkalmazni az Országgyülésről szóló 2012. évi XXXVI. törvény (továbbiakban Országgyűlési törvény) 133. §-a alapján. 
Sőt, nemcsak hogy nincs ilyen, de nem is kell ilyet biztosítani az Európai Emberi Jogi Bíróság (EJEB) joggyakorlata szerint. ${ }^{29}$ Elvileg tehát az Országgyülés elnöke, amennyiben nem külön közigazgatási szerv, például a rendőrség biztosítja az épület védelmét, amelynek hatósági intézkedései vitán felül bírói kontroll alatt állnak, hanem saját őrséggel rendelkezik, ahogy ez jelenleg szabályozva van, akkor akár olyan szabályozás is elképzelhető, hogy az Országgyülési Őrség hatósági intézkedései ellen nincs bírói út, és ez esetben a Kp. közigazgatási jogvita fogalma erre nem fog kiterjedni olyan esetben, ha például ellenzéki országgyűlési képviselőkkel szemben vetnék be az Őrséget, mivel az egyéb közjogi jogvitaként igényelne külön jogorvoslatot biztosító szabályokat.

Még érdekesebb, hogy az EJEB nem követeli meg a kifelé irányuló jogviszonyokban, így a sajtó és az Országgyülés elnöke kapcsolatában sem a bírói utat. ${ }^{30}$ Ez esetben akár az is előfordulhatna, hogy az Országgyűlési Őrség foglyul ejti a nem kívánatos országgyülési képviselőket vagy a sajtó képviselőit, és ez ellen semmilyen jogorvoslat nem állna rendelkezésre. Azért nem ez a helyzet. Úgy vélem, hogy a büntetőjog szabályai - azokkal a korlátokkal, amelyeket a büntetőeljárásjog beépít az Országgyủlés elnöke büntetőjogi felelősségre vonásával kapcsolatban, és amelyek az Országgyủlés Hivatala vagy az Őrség személyzetére már nem vonatkoznak - végső soron a súlyosan táradalomra veszélyes cselekményeknél fellépést biztosítanak a büntetőhatalom szervei számára. Természetesen az egész felvetés elméleti, csak a megértés miatt tartottam fontosnak ezt a gondolatkísérletet.

Az EJEB azzal, hogy nem írja elő a parlamenti jog hatálya alá tartozó személyek parlamenti jogot sértő cselekményeivel szemben a bírói utat mint hatékony jogorvoslat szükségességét - és ebben a hatalommegosztás mint belső szuverenitáshoz tartozó ügy tisztelete érhető tetten -, valójában közvetlen ellenőrzése alá vonja a parlamentek viszonyainak felügyeletét. Az Egyezményt sértő parlamenti aktusokat ugyanis felülvizsgálja, és azok Egyezménybe ütközését megállapítja akár egyéb közjogi jogvitáról, akár a sajtó és az Országgyűlés elnöke vagy annak hivatala közti jogvitáról legyen szó. ${ }^{31}$ Ennyiben minden tagállam érdeke - ha a szuverenitási érveket fontosnak tekintjük - az volna, hogy legyen generálisan bírói út nemcsak a közigazgatás, hanem más hatalmi ágak tekintetében is, tehát az Országgyülés és szervei és maguk a bíróságok igazgatási szervei vonatkozásában, különben ezen viszonyok közvetlenül az Egyezmény hatálya alá rendelődnek, és nem érvényesül általános alapelvként az Egyezmény szubszidiárius jellege.

Mindebböl tehát levonhatjuk a következtetést, hogy a Kp. 4. § (7) bekezdés 1. e) pontja alá tartozó szervek köréböl a Kp. egyéb közjogi jogvita fogalma nem zárja ki ugyan a bíróságokat és az Országgyülést, valamint annak szerveit (alapvető jogok biztosa, Állami Számvevőszék), de az egyéb közjogi jogvita körébe eső, alkotmány-

${ }^{29}$ EJEB, Karácsony és mások Magyarország elleni ügye: 42461/13. és 44357/13. számú kérelmek, a Nagykamara 2016. május 17-én kelt ítélete; 164., 174. pontok.

30 EJEB, Mándli és mások Magyarország elleni ügye, 63164/ 16. számú kérelem, az EJEB 2020. május 26-án kelt ítélete; 72-84., 92.3. pontok.

31 Lásd a 29. és 30. lábjegyzetben feltüntetett ügyeket, melyekben az EJEB az Egyezmény 10. cikkének megsértését mindkét esetben megállapította. 
jogi szabályozás tárgyát képező közjogi szervezeten, illetve szervezetrendszeren belüli jogviták lehetőségét a Kp. más szabálya kizárja. Ezért nem, a cselekményt megvalósító alanyi oldal hiánya, hanem a közigazgatási jogi szabályozottság hiánya és annak a személynek a jogviszonyban betöltött minősége, akire irányul a cselekvés, tehát a cselekvést elszenvedő jogalany (a jogviszony közvetett tárgya) az, ami valójában megkülönbözeti a két jogvitatípust.

Ennek alátámasztására jónak tủnik a német példa, mert a német alkotmányjog alapján a közjogi helyzet hasonló a magyarhoz. A házelnök gyakorolja a Bundestag épületével kapcsolatos rendőrségi és „házi” jogot, ${ }^{32}$ és a házszabály alapján mindenki (újságírók és érdeklődök) kizárólag a házelnök belépési engedélye birtokában tud bemenni, amit kérelem alapján állítanak ki. A házelnök a házszabály megsértése esetén bárkit kitilthat. ${ }^{33}$ Az ezzel szembeni jogorvoslat a német Kp. (VwGO) az érintett részben Klaus Rennert, a német szövetségi közigazgatási bíróság korábbi elnöke által jegyzett - nagykommentár szerint az alapvető elhatárolási szempont a közigazgatási és az egyéb közjogi jogviták esetében, hogy a jogviszony szabályozása alkotmányjogi-e, beleértve tágabb értelemben a házszabályjellegü belső szabályzatokat is. Ezzel azonban olyan mértékben kitágulna az alkotmányjogi jogvita (vö. magyar Kp. szóhasználatában „egyéb közjogi jogvita”) fogalma, hogy az olyan ügyek, amelyeknek a tárgya ezek részletszabályain alapuló nem alkotmányos, hanem eljárásjogi vagy alacsonyabb szintű jogforráson alapuló anyagi jogosultságok, is beletartoznának a közjogi jogvita fogalmába, amelyek egyébként közigazgatási perben vitathatók. Itt az elhatárolás azon múlik, hogy a jogvita gyökere mennyiben az alkotmányjog által meghatározott, illetve hogy ezek az „egyszerü” jogosultságok elválaszthatók-e az alkotmányjogi kérdéstől, vagy egybetartoznak-e. Így például a képviselök házelnök viszonylatában a felszólaláshoz vagy a kérdezéshez való képviselői jog kapcsán kialakuló vita az Alkotmánybíróságra tartozik, de a házijog gyakorlása, pl. a hivatali telefon letiltása közigazgatási bírói útra. A német rendszerben azonban a hézagmentes jogvédelem elve töretlenül érvényesül, és a VwGO 40. § éppen azt rendezi, hogy minden, ami nem alkotmányjogi, de közjogi jogvita, az közigazgatási bírói útra tartozik. ${ }^{34} \mathrm{Ez}$ utóbbi feltétel a magyar Kp. esetében nem teljeskörűen érvényesül. Bár a jogalkotó eredeti célkitűzése szerint a hézagmentes jogvédelem elve érvényesült volna a Kp. rendszerében is, ${ }^{35}$ az eredeti Kp. 5. § (2) bekezdésének szövegezése nem az eredeti elgondolás szerint lépett hatályba, amennyiben a jogalkotó csak külön törvényi szabály esetén tereli közigazgatási bírói útra az egyéb közjogi jogvitákat olyan esetben is, ha egyébként az ellen nem biztosított alkotmánybíróságra tartozó jogorvoslat.

${ }^{32}$ Hausrecht, GG 40 (2).

${ }^{33}$ Lásd: https://www.bundestag.de/resource/blob/340518/d733432871694f1b8214a87803213500/ zugangsregeln-data.pdf.

${ }^{34}$ M. HAPP - Klaus RENNERT et al. (szerk.): Eyermann Verwaltungsgerichtsordnung: VwGO. Kommentar (München: C.H.Beck ${ }^{15}$ 2019) 131.

${ }^{35}$ F. RozsnyaI Krisztina: „A közigazgatási perjog néhány alapelvi aspektusa” Acta Humana 2019/1. 112-113., https://doi.org/10.32566/ah.2019.1.6; lásd még Kp. törvényi indokolását, amely az eredeti szöveg magyarázatát tartalmazza és nem az ezzel ellentétes tartalmú módosított szövegét. 
Mindemellett a német szakirodalom ${ }^{36}$ a házszabály alapján hozott házelnöki döntések körében azt emeli ki, hogy azok lehetnek közjogi és magánjogi természetủek is. Az elhatárolás alapja eszerint, hogy a személy, akivel szemben eljárnak, a parlament alapvető rendeltetése szerinti tevékenységet végez-e. Így a látogatók, kérelmezők stb., akik a parlament „rendes” müködése körében akarnak a parlamentbe bejutni, közigazgatási úton támadhatják meg a rájuk vonatkozó döntéseket, míg például a szolgáltatók, takarítók magánjogi (munkajogi) úton. Vagyis a házelnök első esetben közhatalmi, a második esetben polgári jogi, munkajogi döntéseket hoz. A közjogi döntések körében további elhatárolás, hogy az intézkedés címzettje maga is lehet közjogi jogalany (pl. képviselö), aki alapvetően alkotmányjogi úton rendezheti a jogvitát, valamint lehet harmadik személy, aki inkább közigazgatási jogi úton. A német rendszerben a konkrét intézkedések a rendőri intézkedésekkel esnek egy tekintet alá, és azzal azonos jogorvoslati út alá tartoznak. ${ }^{37}$

A német jogirodalmi felfogás megerősíti azt a levezetésünket, hogy az elkülönítésnek kettős alapja van, és nem az dönti el a minősítést, hogy a cselekményt közigazgatási szerv végzi-e, hanem egyrészt az, hogy közigazgatási vagy alkotmányjogi szabályozásról van-e szó, beleértve a közigazgatási jogi szabályozásba minden olyan szabályozást is, amely az alkotmányjogi szabályozást bontja le részletszabályokra. Másodsorban az dönti el, hogy az a személy, akire a cselekmény irányul, közjogi szereplő-e avagy nem. A nehéz esetek azok, amikor nem közjogi szereplőről van szó, viszont a szabályozásnak erős alkotmányjogi vetülete van. Ezért a továbbiakban azt kell megvizsgálnunk, hogy a rendészeti jogok gyakorlása külső személyekkel szemben közigazgatási jog által szabályozottnak minősül-e egy országgyűlés vagy egy másik hatalmi ág, a bírósági beléptetési szabályozáshoz kapcsolódó beléptetés esetén.

Ehhez szükséges ismét, immár a lehetséges további ellenvetésekkel együtt megvizsgálni, hogy a közigazgatási jog által szabályozott egyedi döntésekről, illetve általános hatályú rendelkezésekről van-e szó a rendészeti tevékenység megvalósítására való feljogosítás esetén, mert ez dönti el, hogy a Kp. 4. § (7) bekezdés e) pontja szerinti közigazgatási szervnek minősülhet-e egy adott magánjogi vagy akár más államhatalmi ághoz tartozó szervezet függetlenül attól, hogy fő tevékenységüket tekintve közhatalmi feladatot vagy más közfeladatot lát-e el.

\section{KÖZIGAZGATÁSI JOG ÁLTALI SZABÁLYOZOTTSÁG MÁS ÁlLAMHATALMI ÁGAKBAN}

A Kp. előtti bírói gyakorlatból már levezettük, hogy a hazai jog a rendészeti jellegű igazgatási intézkedéseket közigazgatási intézkedésekként, közigazgatási tevékenységként azonosította, csak korábban - a Kp. előtt - ezek ellen külön törvényi rendelkezés hiányában nem volt jogorvoslat. Ugyanígy, a rendészeti intézkedéseket

${ }^{36}$ Martin MorloK - Utz Schliesky - Dieter Wiefelspütz: Parlamentsrecht. Praxishandbuch (BadenBaden: Nomos 2016).

37 MoRloK-Schliesky-WiefelspüTz (36. jl.) § 21. 33, 254. 
szabályozó általános hatályú rendelkezések szükségszerűen közigazgatási általános hatályú rendelkezések, melyek törvényessége megvizsgálható. Megjegyezhető, hogy ez külön nevesítés nélkül korábban is így volt, hisz a törvénybe ütköző szabályzatokat a korábbi bírói gyakorlat is figyelmen kívül hagyta az értékeléskor, ezért az általános hatályú rendelkezések nevesítése a felülvizsgálható döntések között és azok alkalmazásának kizárásáról szóló bírói rendelkezés ${ }^{38}$ tulajdonképp még visszalépés is. Hiszen míg korábban ahhoz valós joghatások csak a közvetetten, diszkriminációtilalmi rendelkezéseken keresztül kapcsolódtak, a Kp. úgy kezeli ezeket, mint ha valódi közvetlen joghatásokat váltanának ki. Úgy tủnhet, amennyiben a közigazgatási ügyekben eljáró bíróság nem rendeli el az adott szabály alkalmazásának kizárását, csak önmagában a törvénysértő voltát állapítja meg, akkor az tovább alkalmazandó. Véleményünk szerint ez nincs így, de ezt a kérdést, mivel a tanulmány tárgyától messze vezet, külön nem elemezzük. Érdemes inkább most a közigazgatási jogi szabályozottsággal kapcsolatos esetleges ellenvetéseket is megvizsgálni.

Az egyik sajátos magyar esetkör az, amikor a külön hatalmi ági jelleghez önálló alaptörvényi szabályozás társul. Így a rendészeti jog gyakorlása alaptörvényi szabályozás hatókörébe kerül - ezzel alkotmányjogiasítva a kérdést -, amikor az Alaptörvény 5. cikk (7) bekezdésének utolsó mondata szerint az Országgyülés működésének biztosítása és méltóságának megőrzése érdekében az Országgyülés elnöke a házszabályi rendelkezésekben meghatározott rendészeti és fegyelmi jogköröket gyakorol. Az Alaptörvény negyedik módosításához fűzött törvényi indokolásból kiderül, hogy ezek a plenáris üléssel összefüggő, kirívóan sértő kifejezések szankcionálását célzó, határozott parlamenti fellépésre vonatkozó rendészeti és fegyelmi jogkörök. Ez egyértelműen kitűnik abból is, hogy házszabályi rendelkezéseken alapuló rendészeti és fegyelmi jogkörről van szó az Alaptörvény szövege szerint, ami tehát az Országgyűlés belső működésére irányuló rendészeti jogköröket jelent. Ezért az Alaptörvényben valóban az egyéb közjogi jogviták fogalmi körébe eső rendészeti jogkörökről van szó.

Az országgyülési törvény 53. §-a e rendészeti jogköröket tovább részletezi, és az alaptörvényi felhatalmazás kereteit átlépi, amikor az 54. § (2) bekezdése felhatalmazást ad az Országgyülésbe való ki- és belépés rendjének általános szabályozására. Ez már minden más külső szereplőre, így sajtó képviselőire is vonatkozik, és egyben rögzíti azt is, hogy az Országgyủlés elnöke nem hozhat olyan rendelkezést, amely az Országgyülés ülésének nyilvánosságát, a demokratikus közvélemény kialakulásához szükséges szabad tájékoztatás feltételeit kizárná.

Megállapítható mindezek alapján, hogy az Országgyủlés épületébe való ki- és belépés rendjét szabályozó házelnöki rendelkezések egy része nem a fenti alaptörvényi szabályon, hanem közvetlenül az országgyülési törvényen alapul, és kifejezetten olyan rendészeti jogköröket szabályoz és nevesít, melyek külső jogviszonyokban érvényesülnek. Ezért a házelnöki rendelkezések a közigazgatási jog által szabályozott cselekmények, konkrétan egyedi ügyben alkalmazandó általános hatályú ren-

${ }^{38}$ Kp. 89. § (1) bekezdés a) pont. 
delkezések, és az e tárgykörben kiadott házelnöki rendelkezések ${ }^{39}$ maguk is közigazgatási jogi szabályokat tartalmaznak. Ezért az ezek alapján az Országgyülés Hivatala által hozott beléptetés engedélyezésére vonatkozó egyedi döntéseket is a közigazgatási jog által szabályozott cselekményeknek kell tekinteni, amennyiben külső jogalanyokra hatnak.

Ha a bíróságok beléptetési szabályait mint a közigazgatáson kívüli másik hatalmi ágat vizsgáljuk, akkor ott e szabályzatok kiadása és a meghozott döntések továbbra sem külön nevesített rendészeti jogkörökön alapulnak, hanem a szervi müködés körében felmerülő szabályzatok. Az eddigiekből az következik, hogy ezek is a közigazgatási jog által szabályozott egyedi döntések, illetve az általános hatályú rendelkezések közigazgatási jogi szabályozást testesítenek meg.

\section{KÖZIGAZGATÁSI JOGI SZABÁLYOZOTTSÁG KÉRDÉSE MAGÁNJOGI SZERVEZETEK ESETÉN}

Az önálló államhatalmi szervek közigazgatási szervi minőségének problémáin túlmenően hasonló probléma merül fel a Kp. 4. § (7) bekezdés 1. e) pont kapcsán a magánjogi szervezetek tekintetében. Kérdésként adódik, hogy lehet-e közigazgatási cselekmények megvalósítására feljogosított szerveknek tekinteni például a bankokat, közműveket vagy egy vállalkozást, ha személy- és vagyonvédelmi szolgáltatásokat vesznek igénybe, és a bekövetkező intézkedésekre az épületet őrző biztonsági szolgálat részéről nem kerül sor, mert előzetes engedélyeken alapszik az épületbe való belépés. Ugyanez a kérdés merül fel, ha valamely belső beléptetési szabályzat alapján bekövetkező rendészeti intézkedés az adott épületben müködő és a vagyonvédelmi szolgáltatást igénybe vevő vállalkozás utasítására történik. Ahogy arról szó volt, ezek az intézkedések is lényegében hatósági intézkedésekre vonatkozó jogorvoslati rendbe tartoznak. Ha elfogadjuk, hogy ezeknek a rendészeti intézkedéseknek a keretei a közigazgatási jog által szabályozottak, akkor felmerül a kérdés, hogy ez tekinthető-e egyfajta általános felhatalmazásnak közigazgatási cselekmények megvalósítására, azaz az e) pont szerinti közigazgatási szervnek minősülnek-e a rendészeti- vagyonvédelmi szolgáltatást igénybe vevő vállalkozások.

E kérdésben érdemes figyelembe venni az Európai Bíróság esetjogát, ${ }^{40}$ melyből levezethető, hogy csak a közfeladatokkal (beleértve általános gazdasági érdekű szolgáltatásokat, tehát közszolgáltatásokat a legtágabb értelemben) összefüggő jogszabály (nemzeti jog) alapján, a magánszemélyek közötti viszonyokban alkalmazandó szabályokhoz képest rendkívüli hatalommal felruházott vállalkozások tekinthetők közigazgatási szervnek az adott rendkívüli hatalom gyakorlása során.

Ez a funkcionális felfogás jó közelítéssel megfelel a Kp. szabályozásának is, és az e) pont szerinti „közigazgatási cselekmény feljogosítására” kifejezés ezzel a tar-

39 9/2013. számú házelnöki rendelkezés.

${ }^{40}$ EuB, Fish Legal és Emily Shirley ügyben 2013. december 19. napján, C-279/12 számú ügyben hozott itélete 84. pont, [ECLI:EU:C:2013:853]. 
talommal jól kitölthető. Ez azt jelenti, hogy a közigazgatás intézményrendszerébe tartozó közigazgatási szervek, és a közintézetek közül a felsőoktatási intézmények a Kp. kifejezett rendelkezése folytán közigazgatási szervek, ha közigazgatási jogi szabályok alapján hoznak egyedi döntéseket, vagy közigazgatási jogi szabályokat tartalmazó általános hatályú rendelkezéseket, míg a többi közintézet, vállalkozás, egyház, köztestület stb. csak akkor tekinthető közigazgatási szervnek az e) pont alapján, ha a közfeladatukhoz kapcsolódó tevékenységröl van szó. ${ }^{41}$

\section{A KÖZIGAZGATÁSI BÍRÓSÁGI FELÜLVIZSGÁLAT TERJEDELME BELÉPTETÉSSEL KAPCSOLATOS JOGVITÁKBAN}

Az eddig kifejtettek alapján meghatározható jogi keretek mellett a bírói felülvizsgálat terjedelme a különböző esetekben a következők szerint alakul.

\subsection{HATÓSÁGI INTÉZKEDÉSEK MINT KÖZIGAZGATÁSI EGYEDI DÖNTÉSEK BÍRÓI FELÜLVIZSGÁLATA}

A rendészeti jogkörök gyakorlása során minden hatósági intézkedéssel szemben, függetlenül attól, hogy magán- vagy középületről van szó, a hatósági intézkedést végző személyekkel szemben van közigazgatási perre lehetőség. Ennek során az intézkedés jogalapja közigazgatási jogi szabályba ütközésre hivatkozással vitatható.

Ezekben az eljárásokban nem vizsgálhatók a hatósági intézkedést elrendelő - az intézkedést mint közigazgatási cselekményt megvalósító „közegeken” kívüli - szervek, szervezetek egyedi döntései, illetve azok általános hatályú rendelkezéseinek betartása, amennyiben ezek a rendelkezések egyébként nem ütköznek jogszabályba. Ha a jogszabályba ütközés megállapítható, akkor ez csak a rendészeti szerven (rendőrség, vagyonvédelmi vállalkozás) kérhető számon, amely ennek következményeit az intézkedő rendőr vagy vagyonőr iránt mint munkáltató tudja csak érvényesíteni, ha felelősségük munkajogi alapon, illetve szolgálati jogviszony alapján megállapítható. Az utasítást adó megbízó szervezetre legfeljebb polgári jogi úton háríthatják át a felelősségből eredő egyes következményeket, mégpedig a polgári jogi felelősségi szabályai szerint, amennyiben annak feltételei fennállnak.

${ }^{41}$ Bizonyos értelemben ez fából vaskarika szabályozás, tekintve, hogy a Kp. 4. § (7) bekezdés a)-c) pontjában nevesített, kifejezetten közigazgatási szervek sem csak e minőségükben járnak el, lehetnek például polgári jogi aktusok alanyai is. Ez azt jelenti, hogy formállogikailag az e) ponton kívül nem volna szükség felsorolásra a Kp. 4. § (7) bekezdésében, mert ezen e) pont alapján ugyanazzal a módszerrel azonosítható be az, hogy a „közigazgatási szerv” éppen közigazgatási szervi minőségben jár-e el, mely beazonosításra akkor is szükség van, ha egyébként a jogszabály kifejezetten jelzi, hogy bizonyos szerveknek mindenképp van közigazgatási szervi minőségük. 


\subsection{BELÉPTETÉS ELÖZETES ENGEDÉLYEZÉSE KÖZSZOLGÁLTATÁST NYÚJTÓ INTÉZMÉNYEKBE, KÖZTESTÜLETEK ÉPÜLETEIBE}

A rendészeti jogköröket gyakorló személyek és szervek által hozott beléptetés engedélyezésére vonatkozó egyedi döntések jogszabályba ütközése nem vizsgálható magánszemélyek és magánvállalkozások esetében közigazgatási perben, de a szervezetileg közigazgatáson kívül elhelyezkedő közintézetek ${ }^{42}$ vagy más őrzött gazdasági közszolgáltatásokat nyújtó épületek beléptetéssel kapcsolatos egyedi döntései vizsgálhatók, amennyiben azok közintézeti jogviszonnyal függenek össze.

Tehát ha egy iskolába járó gyermek szülője kíván belépni egy épületbe, azaz a belépés célja közintézeti jogviszonnyal összefüggésbe hozható, az igazgató által hozott, ezt megtiltó egyedi döntés közigazgatási perben támadható lesz. A kereset a közintézeti jogviszonyra vonatkozó valamely jogszabályi rendelkezésbe (beleértve akár az Alaptörvény alapjogi rendelkezéseit is) ütközésen alapulhat a jogalapot tekintve.

Azonban ha a közintézeti jogviszonnyal nem érintett teljesen idegen személy, nem meghatározható vagy kifejezetten nem a közintézeti jogviszonyhoz kapcsolódó célból kíván belépni (például karbantartási cél, ami a közintézet szervi működéséhez kapcsolódó cél), akkor az azt megtiltó egyedi döntés nem közigazgatási cselekmény, hanem a szervi müködés körébe tartozó tulajdonosi-vagyonkezelöi döntés lesz.

Fontos hangsúlyozni, hogy ha a közintézet szolgáltatását díj ellenében lehet igénybe venni (múzeumi belépő, színház stb.), akkor az ilyen jogviszonyok már nem közigazgatási perre tartoznak, hiszen polgári jogi viszony keletkezik a felek között a jegy megvásárlásával, így a beléptetés megtagadása polgári jogi aktusnak fog minősülni, és így, ebben a jogviszonyban nem minősülhet a Kp. 4. § (7) bekezdés 1. e) pontja szerinti közigazgatási szervnek az adott közintézet.

Amennyiben közintézeti beléptetés kapcsán helye van egyáltalán közigazgatási pernek, akkor ebben az intézmény belső beléptetési szabályzatainak való megfelelés szintén nem kérhető számon, csak a jogszabályi rendelkezéseknek való meg nem felelés vizsgálható - beleértve az egyenlő bánásmód elvét.

A köztestületek esetében, ha köztestületi tagok beléptetéséröl van szó, az a köztestületi jogviszonyokhoz kapcsolódik, és figyelemmel az államháztartás módosításáról szóló törvény $8 / \mathrm{A}$. § szabályára ${ }^{43}$ is, amely mind a belső, mind a külső jogviszonyokra közigazgatási pert rendel alkalmazni, a beléptetés jogalapja tekintetében a kamara illetékes szervének vagy elnökének beléptetést megtiltó döntése e külön szabály miatt fog minden külön elemzés nélkül, a Kp. 4. § (7) bekezdés d) pontja alapján közigazgatási egyedi döntésnek minősülni.

A kamara beléptetési szabályzata esetében az államháztartás módosításáról szóló törvény 8/A. § (6) bekezdése teszi lehetővé a szabályzatnak való megfelelés vizsgálatát (köztestületi jogvita). E szabály, ha nem létezne, akkor ugyanaz lenne a helyzet,

${ }^{42}$ Beleértve a közintézeti feladatokat ellátó, azokkal egy tekintet alá eső más szervezeteket, pl. egyházi, alapítványi intézeteket stb. is.

${ }^{43}$ Az államháztartásról szóló 1992. évi XXXVIII. törvény és egyes kapcsolódó törvények módosításáról szóló 2006. évi LXV. törvény. 
mint bármely közintézet esetén, illetve hatósági ügy intézésével összefüggő beléptetés esetén, mint bármely közigazgatási szerv esetén. Ha nem köztestületi tagról vagy a köztestület müködésével összefüggő beléptetésről van szó, hanem harmadik személyek karbantartási, munkavállalási vagy cél nélküli stb. belépéséről, akkor arra nem a köztestületi vita szabályai, hanem a közintézetekhez hasonlóan polgári jogi, tulajdonosi, illetve munkajogi egyedi döntések kapcsolódnak, melyek közigazgatási jogvita tárgyai nem lehetnek.

\subsection{BELÉPTETÉS ELÖZETES ENGEDÉLYEZÉSE KÖZIGAZGATÁSI SZERVEZETRENDSZERBE TARTOZÓ SZERVEK ÉPÜLETÉBE MINT ÖNÁLLÓ, TELJES ÉS VÉGLEGES EGYEDI DÖNTÉS BÍRÓI FELÜLVIZSGÁLATÁNAK TERJEDELME}

A Kp. 7. § (4) bekezdés a)-c) pontjának megfelelő közigazgatási szerveknél is a belépésröl hozott egyedi döntések (előzetes engedélyek) akkor lesznek csak közigazgatási perben támadhatók, ha a belépés célja valamely közigazgatási ügy intézése. Ez esetben a beléptetési szabályzat megsértése - ha van ilyen - szintén nem vitatható, hanem csak az, hogy a beléptetés valamely jogszabályt megsért-e. ${ }^{44}$

Itt azonban felmerül, hogy ilyen jogszabálynak tekinthetők-e hatósági ügyek intézése esetén a hatósági ügyre vonatkozó eljárási szabályok. Ha egy hatósági ügy ügyfele ügyének intézése érdekében kíván belépni a hatóság épületébe, és nem engedik be, mely által objektíve sérülnek az ügyféli jogai, vagy mondjuk az idézésre való megjelenésének kötelezettségét mulasztja el emiatt, mindezek hatással vannak a hatósági ügy kimenetelére. Közvetetten a hatósági ügyben hozandó érdemi döntés jogszerűségére hathatnak.

A hatósági eljárási szabályok megsértése fogalmilag nem a beléptetés jogszerüségére hat, hanem fordítva: a belépés megtiltása hathat ki a hatósági döntés jogszerűségére. A közigazgatási jogvita fogalmából következik, hogy közigazgatási jogvita tárgya lehet az érintett jogalany jogi helyzetének megváltoztatását eredményező és nem csak az azt célzó aktusok, akár a beléptetés megtiltásából eredő reálaktusok, melyek ilyen módon közvetett joghatásként kihatnak a hatósági ügyben hozandó döntés tartalmára is. Ez pedig felveti azt a kérdést - ami mindegyik eddig tárgyalt esetkörben is releváns -, hogy a belépés megtagadása mint közigazgatási egyedi döntés nem járulékos cselekmény-e, ugyanis ez esetben önállóan nem támadható meg közigazgatási perben. ${ }^{45}$

Határozott válaszom erre az, hogy nem járulékos cselekmények, hanem önálló, teljes és végleges ${ }^{46}$ közigazgatási cselekmények. Alapvetően azért, mert az a

${ }^{44}$ Érdemes megjegyezni, hogy persze más esetben is lehet formálisan közigazgatási pert indítani, csak az érdemben nem lesz sikeres, ha a belépés tiltása szervi működés körébe eső polgári jogi aktuson fog alapulni, aminek jogszerűségét közvetlenül közigazgatási perben nem lehet majd felülvizsgálni.

${ }^{45}$ Kp. 4. § (4) bekezdés b) pont.

${ }^{46} \mathrm{Az}$ Ákr. a jogerős hatósági döntéseket végleges döntésnek nevezi. A végleges döntés fogalma jól használható azonban a nem hatósági jellegű egyedi döntésekre, melyek esetében formális eljárás 
joghatás, amit eredményez a beléptetést megtagadó egyedi döntés, csak közvetett joghatás. Az ügyfélnek erre a hatósági eljárásban hivatkoznia kell. Ha ott nem tud hivatkozni, a belépés megtagadása okán vagy más okból, akkor a döntést megtámadó keresetében hivatkozhat e körülményre, és ha hivatkozik, akkor azt kimentési oknak kell tekinteni, és igazolási kérelemként kell elbírálni. Az igazolási kérelmet elbíráló végzés pedig olyan járulékos cselekmény, amely vitán felül megtámadható az ügyben hozott érdemi döntés, azaz a határozat közigazgatási bírói felülvizsgálata során, és ha az igazolási kérelemnek helyt kellett volna adni, akkor az ki fog hatni a határozat jogszerűségére. Ebből tehát jól látható, hogy a belépés megtagadása mint egyedi döntés, olyan közigazgatási cselekmény, amely az eljáráson kívül jelentkezik, közvetett a joghatása, amit eredményez, így annak felülvizsgálata sem önállóan, sem közvetetten a határozattal együtt nem is történhet meg a hatósági ügyben, mert nem tekinthető az adott eljárás járulékos cselekményének. Ezzel bizonyítottuk, hogy a belépéssel kapcsolatos egyedi döntések önálló, teljes és végleges közigazgatási cselekmények, melyek önállóan támadhatók közigazgatási perben.

Ennek a levezetésnek különös jelentősége van olyan esetben, ha nem hatóság ügyintézésröl van szó. Helyi önkormányzatok esetében jó példa erre a már tárgyalt azon kúriai ítélet, amelyben egy polgármester egyedi döntése az volt, hogy nincs elég szék a képviselö-testület ülésén, ezért bár az nyilvános, de arra nem lehetett beengedni a felperest. Ha járulékos cselekmény volna ez az egyedi döntés, akkor ez egy jogalkotási eljáráshoz kapcsolódó járulékos cselekmény lenne, ami rögtön kizárna mindenféle jogorvoslatot az ilyen egyedi döntéssel szemben. Mivel azonban fentebb bemutattuk, hogy ezek önálló, teljes és végleges egyedi döntések, ezért mint a közigazgatási jog által szabályozott keretek között hozott egyedi döntések támadhatók a Kp. alapján közigazgatási perben. Az más kérdés, hogy az ilyen szóbeli egyedi döntések esetében, amikor még csak egyszerű írásos formát (pl. egy e-mailben közölt elutasító levél) sem ölt az egyedi döntés, a sérelmet elszenvedő felperest terheli az egyedi (szóbeli) döntés létének és tartalmának a bizonyítása (pl. rendőri jelentés).

Ha ez a bizonyítás sikerül is, vagy nem vitatott a közigazgatási cselekmény, akkor annak indokai és bizonyítékai először a védiratban jelennek meg például az alperesi polgármester részéről, mely mögött közigazgatási iratok ugyancsak nincsenek. Ezért minden egyes tényállítást (pl. nem volt üres szék) kérdést valakinek bizonyítania kell. Főszabály szerint annak, aki állít, tehát a saját védiratban előadott indokai tekintetében a tényeket az alperesnek, de nemleges tény esetén alacsony a bizonyítási sztenderd. Kérdés, hogy mivel és hogyan történik a bizonyítás, és mikor fordul meg a bizonyítási teher. Tehát egy ilyen ügyben a bizonyítási nehézségek számosak. Érdemes felhívni arra is a figyelmet, hogy egy ilyen formális indokolás nélküli egyedi döntés esetén, amely azonnal végrehajtásra is került, - tehát lényegében az egyedi döntés az intézkedés típusába tartozik maga is -, nem igazán beszélhetünk megtámadási keresetről, sokkal inkább a cselekmény jövőbeni megvalósításának a

hiányában a jogerő fogalmát nem lehet értelmezni. Az ilyen, nem hatósági, egyedi döntések csak véglegesek lehetnek. Ugyanakkor a véglegessége a döntésnek a közigazgatási per indításának feltétele, mert nem végleges döntések fogalmilag járulékos cselekmények, amelyek valamely végleges döntés meghozatalát szolgálják. 
tiltása, a jogviszonyból eredő kötelezettség teljesítésére kötelezés, tehát marasztalási jellegű kereset, esetleges megállapítási kereset terjeszthető elő. A Kp. szabályozása még némileg hézagos e körben, hiszen a bírót a vádirat nem köti, tehát a bírónak viszonylag szabad mozgástere van abban, hogy az alperes perben előadott vagy a felperes által bizonyított indokokhoz kötve vizsgálódik-e, illetve abban is, hogy a bizonyítási terhet pontosan hogyan is osztja ki.

Fel kell hívni arra is a figyelmet, hogy a beléptetési szabályzatok betartásának figyelmen kívül hagyása épp ebből is adódik. Ugyanis a bírósági joggyakorlat a Jat. alatti általános hatályú rendelkezések tekintetében azt a gyakorlatot alakította ki, hogy amennyiben az ilyen rendelkezésektől a hatóság eltér, akkor azt indokolni köteles, és a jogsértés nem magának a szabályzatnak a megsértése, hanem a kielégítő indokolás megadásának a hiánya, azaz elsősorban az indokolási kötelezettség megsértése (Ákr. 81. §). ${ }^{47}$ Ez a kötelezettség azonban csak a hatósági döntéseket terheli, általában az egyedi döntéseket nem. A hatósági döntéseken kívül más egyedi döntések esetében indokolási kötelezettség hiányában nem kérhető számon a beléptetési szabályzatok betartása a közigazgatási szerven. Ami számon kérhető, az az, ha a beléptetés tiltása kifejezetten a nem hatósági eljárás keretében vizsgálandó közigazgatási jogi jogszabály megsértésében áll. Tipikusan ilyen az a jogszabály, miszerint egy adott ülés nyilvános.

\subsection{A KÖZIGAZGATÁSI BÍRÓI FELÜLVIZSGÁLAT \\ TERJEDELME MÁS ÁLLAMHATALMI ÁGAK SZERVEINEK ÉPÜLETÉBE TÖRTÉNŐ BELÉPTETÉS ESETÉN}

\subsubsection{A MAGYAR BÍRÓI GYAKORLAT}

A Kp. 4. § (7) bekezdés 1. e) pontjába tartozó, a közigazgatási szervezetrendszeren kívül álló más szervek nagy esetköre - a közintézeteken, vagy közfeladatra, illetve rendészeti feladatokra feljogosított magánszervezeteken túl - a más hatalmi ághoz tartozó szervezetek, személyek (köztársasági elnök, Országgyűlés és szervei, bíróságok). Ezek tekintetében annyit tudtunk eddig megállapítani, hogy beléptetéssel kapcsolatos egyedi döntések közigazgatási jog által szabályozottak, továbbá az e) pont csak annyi korlátot tartalmaz, hogy ha ezek a szervek közigazgatási cselekmény megvalósítására vannak feljogosítva, akkor e tekintetben közigazgatási szervnek minősülnek.

${ }^{47}$ Legfelsőbb Bíróság Kfv. III.37.697/2011/9.; Kfv.II.37.076/2012/28. Lásd e gyakorlat eredetét az uniós jogból: C-167/04. sz. P JCB Services kontra Bizottság, EU:C:2006:594, 207. pont, mely hivatkozik a C-189/01. sz. Jippes és mások, EU:C:2001:420; a T-17/99. sz. Ke Kelit kontra Bizottság, EU:T:2002:73 és a Dansk Rørindustri, EU:C:2005:408, 209. pont számú döntésekre. Emellett lásd még T-210/01. sz. General Electric kontra Bizottság, EU:T:2005:456, 516. pont; C-112/77. sz. August Topfer \& Co. GmbH kontra Bizottság, EU:C:1978:94 (jogos várakozások); T-15/02. sz. BASF kontra Bizottság, EU:T:2006:74; T-71/03. sz. Tokai Carbon egyesített ügyek kontra Bizottság, EU:T:2005:220; T-279/02. sz. Degussa kontra Bizottság, EU:T:2006:103; T-52/02. sz. Union Pigments, EU:T:2005:429; C-3/06. sz. Groupe Danone kontra Bizottság, EU:C:2007:88 ügyeket. 
A Kúria - két alsóbb fokú bírósággal egyetértve - mégis úgy látta, hogy nincs helye a Kp. alapján közigazgatási pernek, ha az újságíró belépését az Országgyűlés Hivatala megtiltja egyedi döntésben (e-mailes elutasítás), illetve az Országgyülés elnöke ellen sem lehet pert indítani az ezen döntést megalapozó házelnöki rendelkezésekkel szemben azon az alapon, hogy azok az országgyülési törvény azon szabályát sértik, miszerint a házelnök nem állapíthat meg olyan rendelkezést, amely az Országgyülés ülésének nyilvánosságát, a demokratikus közvélemény kialakulásához szükséges szabad tájékoztatás feltételeit kizárná. ${ }^{48}$

Az érvelés lényegi alapja az, hogy a más hatalmi ágba tartozó államhatalmi szervek, így az Országgyülés és szervei esetén is a Kp. 4. § (7) bekezdés 1. e) pont szerinti közigazgatási cselekmény megvalósítására való feljogosításnak kifejezettnek és határozottnak kell lennie, amelyet a tételes jog kifejezetten hatósági hatáskörök gyakorlására való feljogosítás körében szokott megtenni.

Van ugyan példa más esetre is, például amikor az országgyűlési törvény $27 / \mathrm{F}$. $§$ (1) bekezdése - amely szerint az Országház képe, stilizált képe és sziluettje használatához a Kiemelt Nemzeti Emlékhely Bizottság hozzájárulása szükséges, és amelyről a Bizottság egyfokú eljárásban dönt -, kifejezetten kimondja, hogy az nem közigazgatási eljárás. Ebből az is következhetne, hogy ahol ez nincs kimondva, ott minden más esetben közigazgatási eljárásról van szó, azonban ez könnyen belátható, hogy nincs így. A Kp. bírói értelmezésének logikája éppen fordított. A bíróságok konkrét egyedi feljogosítást, magyarán olyan külön jogszabályt várnak el ilyen esetben, amely kifejezetten közigazgatási cselekménynek, vagy ügynek minősíti a konkrét ügyet vagy eljárást, ennek hiányában, jogértelmezéssel való dogmatikai okfejtést nem tartják elegendőnek. ${ }^{49} \mathrm{Ez}$ a következik abból is, hogy az Alkotmánybíróság az Állam Számvevőszék (ÁSZ) jelentése elleni jogorvoslat kizártsága körében elsősorban arra koncentrált, hogy a pártok ellenőrzése körében hatósági jellegű hatáskörrel volt-e felruházva az ÁSZ, annak ellenére, hogy a Kp. nem csak a hatósági jogkörök esetén engedi a feljogosítást. ${ }^{50}$

\subsubsection{AZ EURÓPA TANÁCS AJÁNLÁSA}

Az, hogy a bíróságok ennyire óvatosak a kérdésben, nemcsak magyar, hanem európai sajátosság. Az Európa Tanács Miniszteri Bizottságának ajánlása szerint nem esnek a közigazgatási aktus fogalma alá a parlament törvényhozó eljárásához kap-

${ }^{48}$ Fővárosi Közigazgatási és Munkaügyi Bíróság 102.K.34.182/2019/2; Fővárosi Törvényszék 11.Kpkf.670.099/2020/2; Kúria Kfv.II.37.452/2020/6 számú végzései.

${ }^{49}$ Klasszikus példája más hatalmi ághoz tartozó szervezet egyértelmű feljogosításának az egyenlő bánásmód hatóság ügyeinek Alapvető Jogok Biztosához telepitése. Lásd a 2021. január 1-jétől hatályos Ebktv. 13.§ (1) bekezdését.

${ }^{50}$ 3304/2020. (VII.24.) AB határozat, lásd AB határozat alapját képező bírósági határozatok kritikáját: F. RozsNYAI Krisztina: „Közigazgatási vita vagy közjogi jogvita, a közigazgatási ügyben eljáró bíróságok végzései a pártok által elfogadott tiltott támogatásokról hozott állai, számvevőszéki jelentésekkel és felhívásokkal szembeni közigazgatási bírói út hiányáról" Jogesetek Magyarázata 2019/4. 17-26. 
csolódó funkciók, ${ }^{51}$ amely egyes európai országokban követett és általánosan elfogadott nézetet tükröz. E nézet szerint a belépéssel a parlamenti jog hatálya alá kerülnek a parlamentbe belépő személyek, és a parlamenti jog nem tartozhat más hatalmi ág, így a bírói kontroll alá sem.

Franciaországban például 1958-ig még a polgári bíróságokkal szemben is immunitást élvezett a Nemzetgyűlés. Majd a francia Államtanács nagyon óvatosan, először csak egy 1999-es döntésével, és kifejezetten az uniós közbeszerzési jogra hivatkozva, ${ }^{52}$ minősítette a Nemzetgyülés elnöke által kötött közbeszerzési szerződést közigazgatási szerződésnek. Ezáltal az Államtanács a Nemzetgyűlés jogi aktusát közigazgatási bírósági eljárás alá vonta, viszont ebben is óvatosan eljárva csak a közbeszerzési szerződésekre állapította ezt meg, lényegében felhívva a jogalkotót arra, hogy szükséges volna e körben a speciális szabályokat megalkotni. ${ }^{53}$

A magyar Kp. előtti általánosan elfogadott irodalmat követve a Kp. Nagykommentárja is úgy foglalt állást, hogy mind az Országgyủlés, mind annak szervei más államhatalmi ághoz tartoznak, és még ha igazgatási tevékenységet végeznek is, és van igazgatási szervezetük, közigazgatási szervnek minősítésük kizárt. ${ }^{54}$

\section{A BÍRÓI HATALMI ÁG ÉS MÁS HATALMI ÁGAK SZÉTVÁLASZTÁSA MÉRTÉKÉNEK KAPCSOLATA A KÖZIGAZGATÁSI JOGVITA TERJEDELMÉVEL}

E fenti gyakorlat a bírói hatalmi ág erős szervezeti és személyi szétválasztottságának megfelelő értelmezést követi, amely mellett a bíróság - amennyiben a kérdést az eljárásjog nyitva hagyja - tartózkodik a tágító értelmezéstől. Ezen megállapításunk alátámasztásához szükséges röviden kitérni a kormányzati tevékenység fogalmára mint közigazgatási bírói hatalmat korlátozó fogalom értelmezésére.

51 ET Miniszteri Bizottság CM (2004) 214. számú ajánlás a közigazgatási aktusok bírósági felülvizsgálatáról, explanatory memorandum (II. General Considerations) A. Comments ont he definitions 1. Administrative acts 12 .

${ }^{52}$ Európai Unió Bírósága, Belga Királyság vs Bizottság, C-323/96, ECLI:EU:C:1998:411.

${ }^{53}$ Marceau Long - Prosper Weil - Guy Braibant - Pierre Delvolvé - Bruno Genevois: Les grands arrêts de la jurisprudence administrative, CE Ass. 5 mars 1999, Président de l'Assemblée Nationale, Rec. 42, concl (Bergeal Dalloz ${ }^{19} 2013$ ) 746-756.

${ }^{54}$ FAzEKAs Marianna: „Közigazgatási szerv tág felfogása a Kp.-ban” in BARABÁs Gergely - F. RozSNYAI Krisztina - Kovács András György (szerk.): Kommentár a közigazgatási perrendtartáshoz (Budapest: Wolters Kluwer 2018) 97.; BARABÁs Gergely - F. RozsnyaI Krisztina: „Közjogi jogvita közjogi perrendtartás - közjogi tevékenység” in BARABÁs Gergely - F. RozSNYAI Krisztina - KovÁcs András György (szerk.): Kommentár a közigazgatási perrendtartáshoz (Budapest: Wolters Kluwer 2018) 153. 


\subsection{KORMÁNYZATI TEVÉKENYSÉG MINT A KÖZIGAZGATÁSI JOGVITA PERESÍTHETŐSÉGÉT KIZÁRÓ ÉRV}

A Kp. 4. § (4) a) pontja kormányzati tevékenységek esetében nem engedi a közigazgatási per lefolytatását. ${ }^{55} \mathrm{~A}$ kormány tevékenységében általában megkülönböztetik a kormányzati működést és a közigazgatás legfelsőbb irányítását. A kettő közül a kormányzati tevékenység, pontosabban az abban való közremüködés a kormány alapvető rendeltetése. A kormányzati tevékenység az ország vezetéséhez tartozó társadalmi, gazdasági, bel- és külpolitikai, védelmi stb. stratégiai célok kitüzését és ezekhez szükséges eszközök és források meghatározását jelenti. Az elöbbiekben meghatározott kormányzati tevékenységet az Országgyülés, a köztársasági elnök és a kormány egymás között megosztva gyakorolja. ${ }^{56}$ Más hatalmi ágak, így az Országgyülés amellett hogy jogalkotási és nem közigazgatási tevékenységet, másrészt kormányzati tevékenységet végez, ezek vonatkozásában közigazgatási szervnek nem tekinthető.

A kormányzati tevékenységek fontos jellemzője, hogy jogilag kötetlen tevékenységek. Ez a tevékenység szabad belátáson alapuló politikai döntést feltételez, és ez a jellege zárja ki a közigazgatási bírói kontrollt. Egy adott tevékenység minél inkább részletszabályok alá esik, annál inkább kötötté válik, és ezáltal annál jobban veszti el kormányzati tevékenység jellegét, és válhat közigazgatási tevékenységgé. Például ha az Országgyülés jogalkotási tevékenységének és a sajtónak a kapcsolata alkotmányos szabályok alapján ítélhető meg, ami az egyéb közjogi tevékenységek jellemzője, és további törvényi és az alatti normatív részletszabályok nincsenek, akkor az jogilag kötetlen, inkább politikai jellegű kormányzati tevékenységnek tủnik. Ám ha az országgyűlési törvény, illetve a házelnök rendelkezései erre részletszabályokat alkotnak, akkor az inkább közigazgatási jogi jellegű tevékenységnek látszik. Ha azonban a házelnöki rendelkezés, mely a beléptetés szabályait meghatározza ${ }^{57}$ nem jogszabály, és annak betartása - ahogy azt fentebb kifejeztük - közigazgatási per keretében nem lesz kontrollálható, akkor a jogvita az alkotmányos elvek ütköztetésének szintjén marad, ami arra utal, hogy ennek sokkal inkább alkotmánybírósági hatáskörnek kellene lennie, mint politikai elemet teljesen nélkülöző, kizárólag szakmai karrierutat bejáró közigazgatási bíró kezébe adott hatáskörnek.

\subsection{KÖZIGAZGATÁSI BÍRÓ VS. ALKOTMÁNYBÍRÓ}

Ha ugyanis az államhatalmi ágak közti hatalommegosztás rendszerében a közigazgatási bírói hatalom más hatalmi ágak viszonyait is kontrollálhatja a közigazgatáson kívül, így beleszólhatna a kormányzati tevékenységbe, az Országgyülés elnökének tevékenységébe, akkor a Kúria elnökét vagy a köztársasági elnök közigazgatási

${ }^{55} \mathrm{Kp} .4 . \S(4)$ a) pont.

${ }^{56}$ FAzeKas Marianna: „Kormányzati aktusok” in FAzeKas Marianna (szerk.): Közigazgatási jog. Általános rész III. kiadás (Budapest: ELTE Eötvös Kiadó 2020) 88-89.

57 Ld. 39. lj. 
jogi szabályok által meghatározott tevékenységét is kontrollálhatná. Az nem vitatott, hogy például egy állampolgársági ügyben hozott köztársasági elnöki határozat - ami egyértelmủen közigazgatási döntés - nem támadható meg közigazgatási perben, ahogy általában a köztársasági elnök döntéseinek bármiféle felülvizsgálatával szemben a bíróságok minden tekintetben tartózkodók. ${ }^{58}$

Ennek azonban nem a Kp. közigazgatási jogvita fogalma szab gátat, hanem az a körülmény, hogy a közigazgatási bírók, akiknek autoritása szakmai alapú, aligha érzik felhatalmazva magukat más hatalmi ágak képviselői „rendszabályozására”. Ez tehát inkább a hatalmi ágak szétválasztásának és a hatalommegosztás elvének tiszteletben tartásából eredő önkorlátozásnak tủnik. Ha ugyanis a közigazgatási bírói hatalom - vagy általában a bírói hatalom - minden más hatalmi ág felett tudna általánosan kontrollt gyakorolni, a törvényhozó hatalmi ág is joggal tarthatna legitim igényt arra, hogy valamiféle politikai kontrollon keresztül hatást gyakorolhasson a közigazgatási bíróságokra. Az ilyen más államhatalmi ágak felé irányuló, illetve államhatalmi ágak közötti feladat- és hatáskörmegosztási viták tipikusan alkotmánybírósági hatáskörök. Az alkotmánybíróságnak az ehhez szükséges legitimitást a magyar rendszer is megadja, amikor az alkotmánybírákat az Országgyülés választja, kialakítva ezzel a kölcsönös ellenőrzés és legitim felhatalmazások rendszerét. A magyar megoldással analóg, hogy ahol a rendes bíróságon belül szervezik meg a hagyományosan alkotmánybíróságinak tekintett hatásköröket, ott természetes, hogy az adott legfelsőbb bírósági fórum bíráit a törvényhozó szerv(ek) választja(k) (lásd Amerikai Egyesült Államok Legfelső Bírósága).

Ha közigazgatási karrierbírák kezébe kerül ez a hatalom, ahogy ez a tendencia a Kp.-val Magyarországon is megindult, az szükségszerűen váltja ki az igényt a politikai aktorok részéröl abba az irányba, hogy ök is valamiféle kiegyensúlyozó kontrollt gyakorolhassanak például a kinevezési jogkörök tekintetében, és ez a nemzetközi példákat tekintve legitim törekvés. Ez a folyamat meg is indult az egyes törvényeknek az egyfokú járási hivatali eljárások megteremtésével összefüggő módosításról szóló 2019. évi CXXVII. törvénnyel, amely megteremtette az Országgyülés által választott alkotmánybírák rendes bírává kinevezésének lehetőségét. ${ }^{59} \mathrm{Nyolc}$ alkotmánybíró élt is a kúriai bíróvá válás lehetőségével 2020 nyarán. ${ }^{60}$ Ebben a megoldásban az az érdekes, hogy ezen bírák esetleges átkerülése a Kúriára azt jelenti, hogy a magyar rendes bírósági rendszerben is meg fognak jelenni - ha közvetetten is - a magyar Országgyülés által választott kúriai bírák, akik minden bizonnyal kellő legitim felhatalmazást érezhetnek arra, hogy más hatalmi ágak viszonyaiba is beavatkozzanak, mely értelmezési lehetőséget a Kp. szövegezése nyitva hagyja.

Az, hogy melyik megoldás a jobb, ha a közigazgatási bírák - és általában a bírák - önkorlátozóan járnak el, vagy az, hogy ha kiterjesztik hatalmukat más hatalmi ágakra, vállalva ezzel a legitim politikai igény megjelenését a bíróságok bizonyos

${ }^{58}$ Lásd például a jogellenesen felmentett és munkaügyi perben a jogellenes felmentés ellenére vissza nem helyezett bírák ügyeit, Kúria Mfv.I.10.461/2013/6, Mfv.10.235/2013/6 ítéletei.

${ }^{59}$ Abtv. 10/A. §.

${ }^{60}$ Domány András: Bíróvá kinevezett alkotmánybírók - irány a Kúria? HVG.hu, 2020. július 3., https:// hvg.hw/itthon/20200703_Birova_kinevezett_alkotmanybirok_irany_a_Kuria. 
mértékű kiegyensúlyozó jellegű politikai kontrolljára, az mindig az adott ország társadalmi körülményeitől, politikai rendszerének sajátosságaitól függ.

\section{KÖVETKEZTETÉSEK}

A tanulmány igyekezett mind a jogorvoslat lehetősége, mind annak terjedelme vonatkozásában teljes körű választ adni arra, hogy középületekbe való beléptetések esetén van-e közigazgatási jogvitára, illetve közigazgatási perre lehetőség, illetve ha van közigazgatási perre lehetőség, annak mi a terjedelme.

Végkövetkeztetésünk, hogy a közigazgatási per lehetősége, mind annak terjedelme függ a belépni szándékozó személy minőségétől és a belépés céljától (közigazgatási tevékenységgel összefüggésben történik-e), függ a beléptetés módjától (előzetes engedélyezés vagy utólagos kontroll érvényesül), a beléptetés szabályaitól (van beléptetést szabályozó jogszabály, vagy csak szabályzat van, vagy az sincs) és a beléptetést érvényesítő személyek, szervezetek jogállásától (tulajdonos vagy rendészeti jogköröket gyakorló személy, szervezet), valamint a középületben folyó közérdekű tevékenység jellegétől, sőt függ a bírósági szervezetrendszer és a bírák hatalommegosztás rendszerében betöltött helyétől.

A részletes következtetéseket talán szükségtelen megismételni, mivel mind a per lehetősége, de különösen annak terjedelme, a fenti változók tükrében más és más.

Amit végkövetkeztetésként általános érvénnyel - függetlenül a beléptetés kérdésétől - rögzíthetünk, az az, hogy minél szélesebb a közigazgatási per indításának lehetősége, és minél szélesebb a vizsgálat terjedelme, annál erősebb a közigazgatási ítélkezés hatása mind a magánszervezetekre, mind más hatalmi ágak működésére. Az utóbbi esetében minél nagyobb a bírói hatalmi ág hatása, annál kevésbé várható a bírói hatalmi ág szigorú szétválasztása elvének következetes érvényesítése a jogi szabályozásban.

A Kp. új szabályozása a hatalmi ágak egymáshoz való viszonyában a közigazgatási bírói hatalmi ágat megerősítette, de ennek terjedelmét nyitva hagyta, részben bírói értelmezés körébe utalta. A bírói értelmezés alakulása pedig a bíróságok alkotmányos jogállása és a bírói jogállás szabályozása, az az más hatalmi ágaktól való szétválasztottságának szintje mentén alakul. Minél inkább szétválasztott a bírói hatalmi ág, annál kevésbé fog élni a Kp. által biztosított hatáskörök olyan kiterjesztő értelmezésével, mely más hatalmi ágak viszonyaiba való beavatkozással jár. Minél kevésbé szétválasztott a bírói hatalmi ág, annál inkább fog más hatalmi ágak müködésébe beavatkozni. A bírói szervezet és a bírák jogállása a szétválasztás szempontjából átalakulás alatt áll, melynek iránya a szigorú szétválasztás ellenében hat. Ez a Kp. hatályba lépésének talán legmesszemenőbb következménye. ${ }^{61}$

${ }^{61}$ Talán túlzásnak tűnik egy szakjogi eseti problémából ilyen nagy ívű általánosításokat tenni. A megállapítások tudományos igazolásához kétségtelen további kutatások és elemzések szükségesek. Jelen tanulmányt egy tudományosan elemezhető kérdés megalapozásának szántam. 